\title{
Total Concentration, Speciation and Mobility of Potentially Toxic Elements in Soils around a Mining Area in Central Iran
}

Giti Forghani ${ }^{*}$, Ahamd Reza Mokhtari ${ }^{2}$, Gholam Abbas Kazemi ${ }^{1}$, Mozhde Davoodi Fard ${ }^{1}$

${ }^{1}$ Faculty of Earth Sciences, University of Shahrood, Shahrood, Iran, Telfax: 00982332396007

*Email: forghani@shahroodut.ac.ir

g_a_kazemi@shahroodut.ac.ir

mozhdeh.davoodifard@gmail.com

${ }^{2}$ Department of Mining Engineering, Isfahan University of Technology,

Isfahan 8415683111, Iran

ar.mokhtari@cc.iut.ac.ir 


\section{Abstract}

The current study was designed to investigate the extent and severity of contamination as well as the fractionation of potentially toxic elements (As, $\mathrm{Cd}, \mathrm{Cr}, \mathrm{Cu}, \mathrm{Pb}, \mathrm{Zn}, \mathrm{Ni}$ ) in minesoils and agricultural soils around a $\mathrm{Pb}-\mathrm{Zn}$ mine in central Iran. For this purpose, 20 agricultural soils and 8 minesoils were geochemically characterized. Results showed that minesoils contained elevated concentrations of As (12.9-254 mg kg-1), Cd (1.255.1-8.5 mg kg-1 $), \mathrm{Pb}\left(137-6239 \mathrm{mg} \mathrm{kg}^{-1}\right)$ and $\mathrm{Zn}\left(516-48889 \mathrm{mg} \mathrm{kg}^{-1}\right)$. The agricultural soils were also polluted by As (5.5-57.1 mg kg $\left.\mathrm{mg}^{-1}\right) \mathrm{Cd}\left(0.15-8.5 \mathrm{mg} \mathrm{kg}^{-1}\right), \mathrm{Pb}(22-3451$ $\mathrm{mg} \mathrm{kg}{ }^{-1}$ ) and $\mathrm{Zn}$ (94-9907 $\mathrm{mg} \mathrm{kg}^{-1}$ ). The highest recorded concentrations for these elements were in soils influenced directly by tailing ponds. Chromium, $\mathrm{Cu}$ and $\mathrm{Ni}$ content in agricultural soils (with average value of $74.1,34.6$ and $50.7 \mathrm{mg} \mathrm{kg}^{-1}$, respectively) were slightly higher than the minesoils (with average value of 54.5, 33.1 and $43.4 \mathrm{mg} \mathrm{kg}^{-1}$, respectively). Sequential extraction data indicated that there were some differences between the speciation of PTEs in soil samples. In the agricultural soils, $\mathrm{Zn}$ and $\mathrm{Cd}$ were mainly associated with carbonate bound fraction, $\mathrm{As}$ and $\mathrm{Pb}$ with reducible fraction, $\mathrm{Cu}$ with oxidisable fraction and $\mathrm{Cr}$ and $\mathrm{Ni}$ with residual phase. With respect to mobility factor values, $\mathrm{Zn}$ and $\mathrm{Cd}$ in the agricultural soils have been found to be the most mobile while As mobility is negligible. Also, the mobility factor of As, Cd and $\mathrm{Pb}$ in agricultural soils adjoining tailing ponds was high. In minesoil sample $\mathrm{Cd}$ was most abundant in the carbonate form, whereas other studied elements were mainly present in the reducible and residual fractions; therefore, despite the high total concentrations of $\mathrm{As}, \mathrm{Pb}$ and $\mathrm{Zn}$ in the minesoils, the environmental risk of these elements was low. Based on the obtained data, a portion of $\mathrm{Cu}, \mathrm{Cr}$ and $\mathrm{Ni}$ input was from agricultural activities.

Key words: Irankuh, potentially toxic elements, tailing ponds, soil, speciation

\section{Introduction}

Mining activity is considered as one of the most hazardous anthropogenic activities in the world (Acosta et al. 2011) and its disruptive effects on the environment have been known for decades. Generally, mining activities are associated with waste production and the disposal of mine wastes often produces more environmental problems than the 
mining operations themselves (Fernandez-Caliani et al. 2009). Mining and processing of $\mathrm{Pb}-\mathrm{Zn}$ ores lead to the production of large amounts of waste rocks and tailings. The disposal of tailings is a major environmental issue that has become more serious with the increasing exploration for metals and the exploitation of lower grade mineral deposits (Ozkan and Ipedoglu 2002). The environmental impacts of tailing ponds generally results from their low $\mathrm{pH}$, low organic matter, scarce or nill vegetation and large amounts of potentially toxic elements (PTEs) (Acosta et al. 2011; Favas et al. 2011). PTEs may be transferred from tailing ponds to nearby soils by acid mine drainage and/or atmospheric deposition of wind-blown dust; thus, mine tailings are one of the most important sources of soil pollution (Siegel 2002; Ferreira da Silva et al. 2004; Boularbah et al. 2006). In recent years, pollution of soil by PTEs in areas adjacent to mine sites has been reported in many countries (Cui and Xin 2011).

Total concentrations of PTEs provide no information on their likely environmental impacts. Furthermore, the speciation studies could be used to determine the mobility and availability of PTEs. Using the sequential extraction procedure, by which the relative contribution of main soil phases in the retention of different elements is determined, it is feasible to predict manner of occurrence, mobility, solubility, bioavailability, toxicity and transport as well as the origin of PTEs (Lasheen and Ammar 2009; Favas et al. 2011; Nannoni et al. 2011).

Irankuh mining area in central Iran contains 23 million tons of lead-zinc ore $(7.4 \% \mathrm{~Pb}$ and $2.4 \% \mathrm{Zn})$. With an annual extraction rate of 358,000 tons of ore, this site is one of the major $\mathrm{Pb}-\mathrm{Zn}$ producers in Iran. Zinc and $\mathrm{Pb}$ concentrates are produced by flotation processes. These processes result in the production of considerable volumes of tailings, which are disposed of in large tailing ponds. Agricultural activities in Irankuh area are extensive and the mine's tailing ponds usually neighbor the farms. The main crops are seasonal including vegetables, barley, and wheat. Potatoes and alfalfa are also cultivated. These products are either locally consumed or marketed in Isfahan, a mega city located nearby. Manure is widely used as fertilizer. The farms are mainly irrigated by local groundwater resources. The present study aims to investigate the mobility and bioavailability of PTEs ( $\mathrm{As}, \mathrm{Cr}, \mathrm{Cu}, \mathrm{Cd}, \mathrm{Pb}, \mathrm{Zn}, \mathrm{Ni}$ ) in soils around this mining zone.

\section{Site description}


Irankuh zinc and lead deposits are located along the Irankuh mountain range, $25 \mathrm{~km}$ southwest of Isfahan in central west Iran (Fig. 1). The climate of the area is semiarid with annual mean temperature of $14.5{ }^{\circ} \mathrm{C}$. Mean annual precipitation is $140 \mathrm{~mm}$, with rain events falling mostly in autumn and spring. In contrast to little rainfall, the mean evaporation rate in the area is $1705.6 \mathrm{~mm}$ year $^{-1}$. Two prevailing wind directions are $\mathrm{W}$ and SW. Incidence of wind erosion process negatively affects soil in the surrounding areas.

\section{Geological setting}

Geologically, the mine site is located in the Sanandaj-Sirjan structural zone, and is one of the $\mathrm{Pb}-\mathrm{Zn}$ deposits on the Isfahan-Malayer mineralization belt. The oldest rocks of this area include green-brown to dark grey shales of Jurassic age. These shales are probably the source rocks for $\mathrm{Pb}-\mathrm{Zn}$ mineralization (Ghazban et al. 1994). Cretaceous carbonate rocks whose thickness is approximately $800 \mathrm{~m}$ overly unconformably Jurassic shales. Stratiform lead and zinc mineralization has occurred in folded Cretaceous carbonate sequence. The main ore and gangue minerals in this mineralization zone include sphalerite $(\mathrm{ZnS})$, galena $(\mathrm{PbS})$, pyrite and marcasite $\left(\mathrm{FeS}_{2}\right)$, chalcopyrite $\left(\mathrm{FeCuS}_{2}\right)$, cerussite $\left(\mathrm{PbCO}_{3}\right)$, hemimorphite $\left(\mathrm{Zn}_{4}\left(\mathrm{Si}_{2} \mathrm{O}_{7}\right)(\mathrm{OH})_{2} \cdot \mathrm{H}_{2} \mathrm{O}\right)$, smithzonite $\left(\mathrm{ZnCO}_{3}\right)$, zincite $(\mathrm{ZnO})$, malachite $\left(\mathrm{Cu}_{2} \mathrm{CO}_{3}(\mathrm{OH})_{2}\right)$, hematite $\left(\mathrm{Fe}_{2} \mathrm{O}_{3}\right)$, limonite and goethite $\left(\mathrm{Fe}_{2} \mathrm{O}_{3} \cdot \mathrm{H}_{2} \mathrm{O}\right)$, barite $\left(\mathrm{BaSO}_{4}\right)$, gypsum $\left(\mathrm{CaSO}_{4}\right)$, dolomite $\left(\mathrm{CaMg}\left(\mathrm{CO}_{3}\right)\right)$ and quartz $\left(\mathrm{SiO}_{2}\right)$. Thus, a variety of metals and metalloids (e.g. As, $\mathrm{Sb}, \mathrm{Cd}, \mathrm{Cu}$ ) are present as minor elements in the ores.

\section{Materials and Methods}

\section{Sampling and sample preparation}

Fig. 1 displays the location of the sampling points. A total of 28 surface soil samples were collected down to $10-20 \mathrm{~cm}$ from zero depth. Twenty samples were collected form soils considered as agricultural soils (contiguous soils). Eight samples are representative of minesoils formed either on host rocks (Cretaceous Carbonates) or source units (Jurassic shales). At each sampling site, a composite sample was obtained by mixing and homogenising five subsamples. After drying in laboratory at room temperature, the large fragments and plant residuals were removed and the remaining portion was passed 
through a $2 \mathrm{~mm}$ stainless steel sieve. The sieved samples were ground to about 0.074 $\mathrm{mm}$ using an agate mortar and pestle and finally stored in polyethylene bags prior to laboratory analysis.

One representative tailing sample was also collected as composite of subsamples from 0 to $20 \mathrm{~cm}$ depth. The sample was air-dried and subsequently homogenized using an agate mortar and pestle.

\section{Analysis}

\section{Physico-chemical properties}

The texture, $\mathrm{pH}$, cation exchange capacity, organic matter and carbonate content of the samples were determined using standard methods. $\mathrm{pH}$ was measured in distilled water with a 1:2 solid/solution ratio after equilibration for 15 minutes (US EPA 1998, Method 9045D). Hydrometery was used to determine the texture of samples. The organic carbon content of the samples was measured by oxidation with potassium dichromate in a strong acid medium (Chopin and Alloway 2007). Back-titration method was implemented to measure the carbonate content. The cation exchange capacity was determined by saturation with $1 \mathrm{M}$ ammonium acetate solution, in a buffered medium at $\mathrm{pH} 7$.

\section{Mineralogical composition}

In order to investigate the mineralogical composition of the samples, three selective soil samples as well as one tailing sample were analysed by using a Philips PW 1800 XRD.

\section{Total element concentration and sequential extraction analysis}

The total concentrations of $\mathrm{As}, \mathrm{Cr}, \mathrm{Cu}, \mathrm{Cd}, \mathrm{Pb}, \mathrm{Zn}$ and $\mathrm{Ni}$ were measured after digesting by four acids $\left(\mathrm{HF}-\mathrm{HClO}_{4}-\mathrm{HNO}_{3}-\mathrm{HCl}\right)$ in an open system (Jeffery and Hutchinson 1983) by ICP-OES (Genesis, Spectro ${ }^{\mathrm{TM}}$ ). The five stage method of Tessier et al. (1979) was employed for sequential extraction analysis. This method is one of the most thoroughly researched and widely used approaches for evaluation of possible chemical associations of metals in sediments and soils. Each of the chemical fractions is operationally defined as follows: 
Extraction 1- Exchangeable fraction $\left(\mathrm{F}_{1}\right)$ : 1 gram soil (dry wt.) was extracted with $8 \mathrm{ml}$ $1 \mathrm{M} \mathrm{MgCl}_{2}$, in a $50 \mathrm{ml}$ glass centrifuge tube for $1 \mathrm{~h}$ at room temperature with continuous agitation. $\mathrm{pH}$ adjusted to 7 using $\mathrm{NaOH}$.

Extraction 2- Weak acid soluble or carbonate-bound fraction $\left(\mathrm{F}_{2}\right)$ : each residue from exchangeable fraction was extracted with $8 \mathrm{ml}$ of $\mathrm{pH} 5$ (adjusted using HOAc), $1 \mathrm{M}$ $\mathrm{NaOAc}$ for $5 \mathrm{~h}$ continuous agitation at room temperature.

Extraction 3- Fe/Mn oxide (reducible) fraction $\left(\mathrm{F}_{3}\right)$ : the residue from the $\mathrm{F}_{2}$ fraction extracted for $6 \mathrm{~h}$ with $20 \mathrm{ml}$ of $0.04 \mathrm{M} \mathrm{NH}_{2} \mathrm{OH} \cdot \mathrm{HCl}$ in $25 \%(\mathrm{v} / \mathrm{v}) \mathrm{HOAc}$ at $96 \pm 3{ }^{\circ} \mathrm{C}$ with occasional agitation. The $\mathrm{pH}$ value was adjusted to 2 using conc. $\mathrm{HNO}_{3}$.

Extraction 4- Organic matter bound (oxidisable) fraction $\left(\mathrm{F}_{4}\right)$ : step 1: $2 \mathrm{ml} 0.02 \mathrm{M}$ $\mathrm{HNO}_{3}$ and $3 \mathrm{ml} 30 \% \mathrm{H}_{2} \mathrm{O}_{2}$ (adjusted to $\mathrm{pH} 2.0$ using conc. $\mathrm{HNO}_{3}$ ) were added to the residue from extraction 3 . The sample was then placed into the oven and heated at $85 \pm 2$ ${ }^{\circ} \mathrm{C}$ for $2 \mathrm{~h}$.

Step 2: an additional $3 \mathrm{ml}$ of $30 \% \mathrm{H}_{2} \mathrm{O}_{2}$ at $\mathrm{pH} 2$ was added to the sample and again heated in the oven at $85 \pm 2^{\circ} \mathrm{C}$ for $3 \mathrm{~h}$, and agitated occasionally.

Step 3: $5 \mathrm{ml}$ of $3.2 \mathrm{M} \mathrm{NH}_{4} \mathrm{OAc}$ in $20 \%(\mathrm{v} / \mathrm{v})$ HOAc was added to the sample and placed into the shaker for $30 \mathrm{~min}$.

Extraction 5- Residual fraction $\left(\mathrm{F}_{5}\right)$ : The residue from the organic fraction was digested by a $\mathrm{HF}-\mathrm{HClO}_{4}$ mixture.

After each successive extraction, separation was achieved by centrifuging at $4000 \mathrm{rpm}$ for 30 minutes. The supernatants were separated with a pipette. The residue was washed in $8 \mathrm{ml}$ deionized water and again centrifuged for 30 minutes. The wash water was decanted. The supernatants were filtered through a $0.45 \mu \mathrm{m}$ membrane. The solutions were analyzed for $\mathrm{As}, \mathrm{Cd}, \mathrm{Cr}, \mathrm{Cu}, \mathrm{Ni}, \mathrm{Pb}$ and $\mathrm{Zn}$ using a Valian 735 ICP-OES. The quality of the sequential extraction procedure was checked by comparing, for each element, the sum of concentrations in five soil fractions with the respective total soil content. The average recoveries of $\mathrm{As}, \mathrm{Cd}, \mathrm{Cr}, \mathrm{Cu}, \mathrm{Ni}, \mathrm{Pb}$ and $\mathrm{Zn}$ were 112.1, 117.1, $106.1,109.3,104.8,103$ and 107.8 percent, respectively.

\section{Data analysis}

Using SPSS 11.5 software for windows, descriptive data analysis on elements concentrations, $\mathrm{pH}, \mathrm{CEC}, \mathrm{OM}$ and carbonate content of soils was applied. The distribution of the data set was tested for normality by kdmogorov-smirnove (k-s) test; 
when the distribution was not normal (e. g. for $\mathrm{As}, \mathrm{Cd}, \mathrm{Pb}$ and $\mathrm{Zn}$ concentration data), the data were log-transformed before statistical treatment. After normalization of the data set, the Pearson correlation analysis was used to determine the relationship between total concentrations of major and trace elements.

To assess the anthropogenic contamination of soil by PTEs and to estimate the enrichment of metal, geoaccumulation index ( $I_{g e o}$, Müller 1969), combined pollution indexes (CPI, Li et al. 2011) and pollution load indexes (PLI, Tomilson et al. 1980) were all calculated by taking into account the total element concentrations.

\section{Results and discussion}

\section{Physico-chemical Properties}

Table 1 displays the physic-chemical properties of the soil and tailing samples. According to the standard classification of United States Department of Agriculture (USDA, 2003), the agricultural soils are of medium to coarse size, while the minesoils and tailings are medium. The average $\mathrm{pH}$ of the agricultural soils and minesoils is 7.9 and 8.3, respectively. The amount of organic matter in agricultural soils ranges from 0.3 to $1 \%$; for minesoils, it falls within the range of 0.02 to $1.1 \%$. The average cation exchange capacity (CEC) in agricultural soils and minesoils is 15.5 and $13.2 \mathrm{cmol} / \mathrm{kg}$, respectively. Cation exchange capacity depends on the amount of sodium-potassium salts, clays, hydroxides of iron and manganese and the organic matter of samples. The CEC of the soil samples tends to increase with organic matter content $\left(r^{2}=0.16\right)$ and the percent of the clay fraction $\left(\mathrm{r}^{2}=0.33\right)$ (Fig. 2a). The average carbonate content of agricultural soils and minesoils are 42.2 and 41.4, respectively. The carbonate content of the soil was positively correlated with $\mathrm{pH}\left(\mathrm{r}^{2}=0.55\right)$ (Fig. 2b). Given the high carbonate content of the samples, the soils have a high capacity to retain PTEs through adsorption and/or co-precipitation mechanisms. The high carbonate content of the samples is inherited from the parent materials and/or soil amendment with limestone. On the basis

of physico-chemical properties of the soils, the agricultural soils and minesoils are Torrifluent and Entisoils, respectively.

The values of the particle size fractions in tailing sample is $26 \%$ sand, $50.3 \%$ silt, and $23.7 \%$ clay; it is therefore classified as silty clay loam. The studied tailing sample has alkaline $\mathrm{pH}(7.8)$, low organic matter content $(0.25 \%)$, high carbonate calcium (42\%) and high CEC values $(12.1 \mathrm{cmol} / \mathrm{kg})$. 
Mineralogical analysis by XRD indicate the presence of dolomite, quartz, muscovite, illite, bassanite, albite in the tailing sample; the soil samples contain nitratine, orthoclase, calcite, dolomite, quartz, montmorillonite, kaolinite, illite, albite, hollandite and clinochlore (Table 2).

\section{Element Concentrations}

The total element concentrations in the soils and tailings from Irankuh area are presented in Table 3. For assessing soil quality, the obtained results were compared with global soil average values (Fig. 3). The average concentrations of $\mathrm{As}, \mathrm{Cd}, \mathrm{Pb}$ and $\mathrm{Zn}$ in the minesoils and the agricultural soils exceed the values for global soil average defined by Kabata-Pendias (2011). When compared, the average concentrations of $\mathrm{Cr}, \mathrm{Cu}$ and $\mathrm{Ni}$ are slightly higher in the agricultural soils than in the minesoils; whereas $\mathrm{As}, \mathrm{Cd}, \mathrm{Pb}$ and $\mathrm{Zn}$ are more enriched in minesoils (Fig. 3). Also, the distribution of total $\mathrm{As}, \mathrm{Cd}, \mathrm{Pb}$ and $\mathrm{Zn}$ concentrations is not normal and follows skewed distributions to higher values (Fig. 4) and their coefficient of variations is greater than 1 (Table 3). However, $\mathrm{Cu}, \mathrm{Ni}$ and $\mathrm{Cr}$ follow distributions closer to normal. Therefore, it can be inferred that the area is probably more contaminated with the elements of the first group, and is less polluted with the second group of elements. In agricultural soils, the highest $\mathrm{As}, \mathrm{Cd}, \mathrm{Pb}$ and $\mathrm{Zn}$ concentrations were recorded in soils near the tailing ponds: these soils contain up to $9907 \mathrm{mg} \mathrm{kg}^{-1} \mathrm{Zn}, 3451 \mathrm{mg} \mathrm{kg}^{-1} \mathrm{~Pb}, 8.5 \mathrm{mg} \mathrm{kg}^{-1} \mathrm{Cd}$ and $57.1 \mathrm{mg} \mathrm{kg}^{-1} \mathrm{As}$; thus they are probably transported from tailings to agricultural soils by wind, as dust particles. The high concentration of As (96 mg kg-1), Cd (17.9 $\left.\mathrm{mg} \mathrm{kg}^{-1}\right), \mathrm{Pb}\left(2835 \mathrm{mg} \mathrm{kg}^{-1}\right)$ and $\mathrm{Zn}$ (6689.5 $\mathrm{mg} \mathrm{kg}^{-1}$ ) in the tailing sample (Fig. 5) supports this conclusion.

Besides comparisons with the global soil average values, the geoaccumulation index $\left(I_{g e o}\right)$ of PTEs was also calculated as follows (Müller 1969):

$$
I_{g e o}=\log _{2}\left[C_{n} / 1.5 B_{n}\right]
$$

where $C_{n}$ is the concentration of the examined element ' $n$ ' in the soil samples and $B_{n}$ is the concentration of element ' $n$ ' in average shale (Turekian and Wedepohl 1961). Müller (1969) has identified seven classes of $I_{\text {geo }}$ (Table 4). Fig. 6 displays sample percentages in Müller classes for the studied elements. For $\mathrm{Cr}, \mathrm{Cu}$ and $\mathrm{Ni}$, more than $50 \%$ of the samples fall in unpolluted to moderately polluted class.

The single-factor index $\left(P_{i}\right)$ was calculated as proposed by Li et al. (2011): 


$$
P_{i}=\frac{C_{i}}{C_{0}}
$$

where $C_{i}$ is the concentration of the element in question in the soil sample and $C_{o}$ is the assessment criterion for each element. The average soil composition as reported by Kabata-Pendias (2011) was used as the assessment criterion. There are five levels for $P_{i}$ (Table 4). Following $P_{i}$ classification, the soil samples of the Irankuh area can be categorized as follows (Table 5): deficient or clean with $\mathrm{Cr}$, slightly polluted with $\mathrm{Cu}$ and $\mathrm{Ni}$, moderately polluted with $\mathrm{As}$ and highly polluted with $\mathrm{Cd}, \mathrm{Pb}$ and $\mathrm{Zn}$. Based on the $P i$ classification, the magnitude of metal contamination of the Irankuh soil samples yields the following ranking: $\mathrm{Zn}>\mathrm{Pb}>\mathrm{Cd}>\mathrm{As}>\mathrm{Ni} \geq \mathrm{Cu}>\mathrm{Cr}$. The values of single-factor index for the studied soils are in agreement with geoaccumulation index results.

Abrahim and Parker (2008) developed Combined Pollution Index (CPI) as follows:

$$
C P I=\frac{\sum_{i=1}^{i=n} P_{i}}{n}
$$

where ' $n$ ' is the number of analyzed elements. These researchers defined a classification for CPI (Table 4). CPI values showed that agricultural soils are less polluted than minesoils (Table 5). Also, agricultural soils near the tailing ponds show high CPI values, confirming that the wind transport of particles containing PTEs is the main cause of soil contamination in this area. This is in accordance with general wind directions in the study area.

A quantitative approach of the multi-element contamination can be made based on the Pollution Load Index (PLI) of Tomilnson et al. (1980):

$$
\mathrm{PLI}=\left(P_{i 1} \times P_{i 2} \times P_{i 3} \times \ldots P_{i \mathrm{n}}\right)^{1 / \mathrm{n}} .
$$

The highest PLI calculated (16.95) is that of an agricultural soil sample around the tailing ponds, which shows the impact of tailing ponds on the contamination of agricultural soils.

\section{Speciation of PTEs}

Sequential extraction is the best available method to yield information regarding the manner of occurrence, bioavailability, mobilization, transport and source of PTEs (Lasheen and Ammar 2009). In this study, three samples from agricultural lands (samples A1 and A7 nearby the tailing ponds and sample A17 away from the mine site) 
and one sample from mine area (Sample M1) were selected. The fractionation of As, $\mathrm{Cd}, \mathrm{Cu}, \mathrm{Cr}, \mathrm{Ni}, \mathrm{Pb}$ and $\mathrm{Zn}$ in four selected soils are given in Fig. 7.

In the studied soils, As was mainly found in the reducible fraction. The next most abundant fraction of As was the residual phase. Exchangeable fraction was the least abundant fraction for As, probably due to the alkaline nature of the samples. In general, As (V) sorption is maximized at acidic $\mathrm{pH}$, and gradually decreases with increasing $\mathrm{pH}$ (Arai 2011). On the other hand, the strong association of As with reducible phases is probably due to the geochemical affinity of this element to Fe-Mn oxides, especially in soils with $\mathrm{pH}>7$ (Kabata-Pendias 2011). According to Tessier et al. (1979), the residual fraction consists of detrital silicates, refractory organic materials and resistant sulfides. Indeed, arsenic usually appears in the form of $\mathrm{As}^{3+}$ in sulphide minerals; therefore, the presence of As in residual phase may be due to the isomorphic substitution of $\mathrm{As}^{3+}$ in pyrite, marcasite and galena (Kreidie et al. 2011).

Due to the low concentration of $\mathrm{Cd}$ in the agricultural soil sample located far from the mine site (Sample A17 with $0.25 \mathrm{mg} \mathrm{kg}^{-1}$ total $\mathrm{Cd}$ ), this element exists only as bound to the reducible and residual phases. The low total concentration of $\mathrm{Cd}$ and its presence in reducible and residual fractions indicates that soils far from the mine site are not polluted by this element. Presence of $\mathrm{Cd}$ in the oxide phase is due to the neutral to alkaline $\mathrm{pH}$ of samples; in soils whose $\mathrm{pH}$ is greater than 7.5, iron hydroxides are suitable sites for absorption of Cd (Favas et al. 2011). Samples A1, A7 and M1 with high total content of $\mathrm{Cd}$, this metal exists mainly in the carbonate phase; other studies show that in soils containing elevated Cd levels, precipitates of $\mathrm{Cd}$ carbonates (e.g. otavite, $\mathrm{CdCO}_{3}$ ) are expected (Anju and Banerjee 2010; Nannoni et al. 2011). Also substitution of $\mathrm{Cd}^{2+}$ for $\mathrm{Ca}^{2+}$ in calcite and precipitation of $\mathrm{CdCO}_{3}$ is expected at high pH (Ghrefat et al. 2012). The mean Cd value in oxidisable fraction of the studied soils was $10.2 \%$. Such small amount is commonly found in soils and sediments, because Cd is not strongly bound to this fraction (Banerje 2003). Low solubility of Cd compounds and smaller values of stability coefficients of organic complexes of $\mathrm{Cd}$ might be contributing to this issue (Mahanta and Bhattacharyya 2011).

Chromium was mainly found as residual phases in the studied soils. Similar results have shown that $\mathrm{Cr}$ is mainly present in the residual phase of soils, because $\mathrm{Cr}^{3+}$ replaces $\mathrm{Fe}^{3+}$ and $\mathrm{Al}^{3+}$ in silicate minerals, especially clays (Chen et al. 2005). Mineralogical composition of selected soils in the study area points to the presence of 
$\mathrm{Cr}$ in silicate minerals, e.g. clinoclore (Table 2). Based on Fig. 7, in the agricultural soils, the amount of $\mathrm{Cr}$ associated with organic matter is higher than in the minesoil. In sludge-amended soils a large fraction of the total $\mathrm{Cr}$ can be associated with soil organic matter (Ma and Hooda 2011).

In agricultural soils, $\mathrm{Cu}$ appeared to be associated predominantly with organic fraction, which may be due to extensive application of manure in the study area. The applied manure contains high concentration of $\mathrm{Cu}\left(72 \mathrm{mg} \mathrm{kg}^{-1}\right)$. The preferential $\mathrm{Cu}$ binding onto organics could be due to both the ease of complexation of $\mathrm{Cu}$ (II) with particulate humic and amino acids ( $\mathrm{Du}$ et al. 2008) and to the greater stability of organic-Cu complexes (Mahanta and Bhattacharyya 2011). This has been ratified by a number of researchers (e.g. Lasheen and Ammar 2009). In the minesoil sample, $\mathrm{Cu}$ appeared to be associated predominantly with the residual fraction. Other studies also reported that $\mathrm{Cu}$ in minesoils is usually associated with residual phase (e.g. Favas et al. 2011). The high proportion of $\mathrm{Cu}$ in the residual fraction is likely due to the fact that $\mathrm{Cu}$ is chemisorbed on or incorporated in clay minerals (Yuan et al. 2004); mineralogical data of the studied soils (Table 2) shows the presence of clay minerals in the studied soils which confirms this conclusion.

In the studied soils, $\mathrm{Pb}$ was predominantly found as reducible fraction; this finding is in agreement with the results of similar studies on mining and smelting areas (Nanonni et al. 2011; Martinez-Martinez et al. 2013). Fe-Mn oxy-hydroxides are important scavengers of metals in soils particularly at $\mathrm{pH}>7$ (Anju and Banerjee 2010); in alkaline soils, stable phases such as hematite and goethite may occur (Arias et al. 2008). In agricultural soils located close to the tailing ponds, a high proportion of total $\mathrm{Pb}$ was associated with carbonates. This form of lead is mainly in carbonate phases such as cerussite $\left(\mathrm{PbCO}_{3}\right)$ and hydro-cerussite $\left[\mathrm{Pb}_{3}\left(\mathrm{CO}_{3}\right)_{2}(\mathrm{OH})_{2}\right]$ which may play an important role in the mobility and bioavailability of this element (Nanonni et al. 2011). $\mathrm{CaCO}_{3}$ might also act as a strong adsorbent for $\mathrm{Pb}$ and could form a complex like $\mathrm{CaCO}_{3} \cdot \mathrm{PbCO}_{3}$ (Anju and Banerjee 2010).

The general fractionation pattern of $\mathrm{Zn}$ is similar to $\mathrm{Cd}$ in the studied soils, indicating comparable environmental behaviour of the two. In agricultural soils adjacent to the tailing ponds, $\mathrm{Zn}$ is mainly associated with carbonate phase, suggesting that calcite $\left(\mathrm{CaCO}_{3}\right)$ may act as a strong sink for $\mathrm{Zn}$. In such a case, $\mathrm{Zn}$ could exist in the form of complex solid phases such as $\mathrm{CaCO}_{3} \cdot \mathrm{ZnCO}_{3}$ (Martinez-Martinez et al. 2013). 
Other acid-soluble minerals could be smithsonite $\left(\mathrm{ZnCO}_{3}\right)$, sulphates and oxidesulphates whose presence was detected in the contaminated soils collected in mining and smelting areas (Nanonni et al. 2011). In contrast, reducible $\mathrm{Zn}$ was the most dominant fraction in the agricultural soil sample located away from the mine site (Sample A17) and also in the minesoil (sample M). Association of $\mathrm{Zn}$ with the reducible phase is due to its tendency to oxy-hydroxides, especially in alkaline conditions (Korfali and Davies 2004). The high percentage of $\mathrm{Zn}$ in the residual phase of minesoil (43\%) may be due to the presence of this metal in montmorillonite (Table 2) and resistant sulphide minerals which were not extracted in the previous steps of the sequential extraction analysis (Tessier et al. 1979). Zn did not exceed 10\% in the exchangeable fraction in non of the studied sample. This observation is probably due to the alkaline nature of the soil samples, since it is well known that $\mathrm{Zn}$ tends to be adsorbed by cation exchange processes in acidic conditions (Favas et al. 2011).

Nickel in the studied soils was mainly associated with the residual phase. Other studies have also pointed to the same circumstances in soils in $\mathrm{Pb}-\mathrm{Zn}$ mining districts (Anju and Banerjee 2011). The presence of $\mathrm{Ni}$ in the residual phase is an indication of its occurrence as inclusions in silicate networks of smectite and illite (Table 2), or its isomorphic substitution with Fe and $\mathrm{Al}$ in the spinel group minerals (Favas et al. 2011). A relatively high portion of $\mathrm{Ni}$ in the agricultural soils (24.2\%) and minesoil (33.9\%) was associated with reducible fraction, perhaps due to the alkaline $\mathrm{pH}$ of the soils and the siderophile characteristics of this element (Taylor and Kesterton 2002; Hang et al. 2009). The higher percentage of $\mathrm{Ni}$ associated with the oxidisable phase in the agricultural soils, when compared to other samples, demonstrates the impact of agricultural activities on increasing mobility and bioavailability of $\mathrm{Ni}$.

\section{Mobility of PTEs}

The mobility of PTEs in soils generally decreases in the order of extraction sequence (Mahanta and Bhattacharyya 2011); thus elements in exchangeable (F1) and carbonate (F2) fractions are more mobile (Alomary and Belhadj 2007; Yan et al. 2010). The higher the $F_{1}$ and $F_{2}$ fractions of a specific metal in the soil, the greater the plant uptake of that metal (Ma and Rao 1997; Alomary and Belhadj 2007; Naji et al. 2010; Yan et al. 2010). The relative index of metal mobility was calculated as 'mobility factor' (MF) using the following equation proposed by Kabala and Singh (2001): 


$$
M F=\frac{F_{1}+F_{2}}{\sum \text { f ractions }} \times 100
$$

Fig. 8 shows the mobility factor of studied elements. The proportion of mobile to the total sum of fractions for $\mathrm{Zn}, \mathrm{Cd}, \mathrm{Cu}$ and $\mathrm{Pb}$ in agricultural soils is appreciably high (the average value for these metals was $45.7 \%, 45.2 \%, 32.2 \%$ and $29.3 \%$, respectively). Minesoil sample showed a low mobility factor for As $(0 \%), \mathrm{Cu}(0 \%), \mathrm{Ni}(0 \%), \mathrm{Pb}$ $(6.2 \%)$ and $\mathrm{Zn}(3.5 \%)$. On the basis of the MF values, the order of mobility in studied soils was as $\mathrm{Cd}(47.6 \%)>\mathrm{Zn}(24.6 \%)>\mathrm{Pb}(17.7 \%)>\mathrm{Cu}(16.1 \%)>\mathrm{Ni}(6.4 \%)>\mathrm{Cr}$ (5.3\%) As (4.3\%).

\section{Source of PTEs}

Correctly distinguishing between natural and anthropogenic metal contents in soils is crucial for assessing soil contamination (Desaules 2012). The sequential extraction data could be used to determine the source of PTEs. This is because the anthropogenically sourced elements preferentially partition to the non-residual phase of the soil, while the residual phase generally reflects background geochemical conditions (Forghani et al. 2009). Inter-element relationships can also provide useful information on the element sources and pathways (Lu and Bai 2010).

Fig. 9 presents the element concentrations in non-residual and residual phases of the soil samples of the study area. The results indicate that in the agricultural soils, for all the studied elements except $\mathrm{Cr}$, the sum concentrations of the non-residual fractions were significant. Also, in minesoil sample, for all the studied elements except $\mathrm{Cr}$ and $\mathrm{Ni}$, the sum contents of the non-residual fractions were considerable. Therefore, in these samples, the anthropogenic sources contributed little to $\mathrm{Cr}$ and $\mathrm{Ni}$ budget. Inter-element relationships (Table 6) also support this statement. The significant positive correlation between lithogenic elements and $\mathrm{Cr}$ and $\mathrm{Ni}$ indicates that these two metals originate from natural sources. On the other hand, significant negative correlation $(p<0.01)$ between $\mathrm{As}, \mathrm{Cd}, \mathrm{Pb}$ and $\mathrm{Zn}$ and lighogenic elements (e.g. Al, Sc, Zr, V and Ti) can be interpreted as their introduction to soil through the anthropogenic sources. Significant positive correlations exist between $\mathrm{As}, \mathrm{Cd}, \mathrm{Pb}$ and $\mathrm{Zn}$, confirming their similar geochemical behaviour (e.g. isomorphism of $\mathrm{Zn}-\mathrm{Cd}$ in wurzite and $\mathrm{As}-\mathrm{Pb}$ in galena), their similar contamination levels and/or the same input sources such as mining activities (Li and Feng 2012; Wang et al. 2010). 
No significant correlation has been observed between $\mathrm{Cu}$ and the rest of the elements, possibly due to a separate source for $\mathrm{Cu}$. Since the average concentration of $\mathrm{Cu}$ in agricultural soils was higher than in minesoils (Fig. 3) and the percentage of $\mathrm{Cu}$ associated with organic matter fraction of the agricultural soils was relatively high $(31.9 \%)$, the origin of this element is thought to be agricultural activities. The high concentration of $\mathrm{Cu}$ in manure $\left(72 \mathrm{mg} \mathrm{kg}^{-1}\right)$ is in agreement with this viewpoint.

\section{Summary and Conclusions}

This study assessed the total as well as fractional concentrations of $\mathrm{As}, \mathrm{Cd}, \mathrm{Cr}, \mathrm{Cu}, \mathrm{Pb}$, $\mathrm{Zn}$ and $\mathrm{Ni}$ in minesoils and agricultural soils around the Irankuh $\mathrm{Pb}-\mathrm{Zn}$ mine, located in central Iran. In the area studied, agricultural soils and minesoils contained similar concentrations of $\mathrm{Cr}, \mathrm{Cu}$ and $\mathrm{Ni}$, while $\mathrm{As}, \mathrm{Cd}, \mathrm{Pb}$ and $\mathrm{Zn}$ were present in higher concentration in minesoils.

The concentration of elements studied exceeded the global soil average defined by Kabata-Pendias (2011). The highest concentrations for $\mathrm{As}, \mathrm{Cd}, \mathrm{Pb}$ and $\mathrm{Zn}$ were recorded in the soils influenced by the tailing ponds, pointing to the necessity of reclamation programs in the area.

The sequential extraction data revealed different partitioning patterns for the PTEs considered in this study. Also, PTEs speciation showed notable differences in agricultural soils and minesoils. In agricultural soils, $\mathrm{Cd}$ and $\mathrm{Zn}$ were mainly associated with the carbonate fraction, $\mathrm{As}$ and $\mathrm{Pb}$ with the reducible fraction, $\mathrm{Cu}$ with the organic matter fraction and $\mathrm{Cr}$ and $\mathrm{Ni}$ with residual fraction. In minesoil sample, major portions of the studied elements, except $\mathrm{Cd}$, were contained in the least mobile fractions (reducible and residual fractions).

The calculated mobility factors indicate that despite high total concentrations of $\mathrm{As}, \mathrm{Cd}, \mathrm{Pb}$ and $\mathrm{Zn}$ in the minesoils, the mobility factor only suggests potential dangerous situation of $\mathrm{Cd}$ contamination, while the contamination risk of $\mathrm{Zn}, \mathrm{Cd}, \mathrm{Cu}$ and $\mathrm{Pb}$ in agricultural soils is considerable and the highest mobility factor of these metals was found in the agricultural soils adjacent to the tailing ponds. The highest mobility factor of $\mathrm{Cr}$ was found in the agricultural soil located far from the mining site.

It is widely known that $\mathrm{Cu}$ and $\mathrm{Zn}$ are essential elements required in trace amounts for plant growth as well as human and animal health in normal levels, but in elevated concentrations they are toxic to organism. Arsenic, $\mathrm{Pb}$ and $\mathrm{Cd}$ are toxic for 
living organisms even at low concentrations. Therefore, it is recommended to take measures to prevent further transfer of tailing particles into the neighboring agricultural lands.

\section{Acknowledgement}

This research has been funded by the Research Office of the University of Shahrood.

\section{References}

Abrahim, G. M. S., Parker, R. J., 2008. Assesment of heavy metal enrichment factors and the contamination in marine sediments from Tamaki Esturary, Auckland, New Zealand. Environ Monit Assess 136, 227-238.

Acosta, J. A., Faz, A., Martinez, S., Zornoza, R., Carmona, D. M., Kabas, S., 2011. Multivariate statistical and GIS-based approach to evalute heavy metals behavior in mine sites for future reclamation. J Geochem Explor 109, 8-17.

Alomary, A. A., Belhadj, S., 2007. Determination of heavy metals (Cd, Cr, Cu, Fe, Ni, $\mathrm{Pb}, \mathrm{Zn}$ ) by ICP-OES and their speciation in Algerian Mediterranean sea Sediments after a five-stage sequential extraction procedure. Environ Monit Assess 135, 265280.

Anju, M., Banerjee, D. K., 2010. Comparison of two sequential extraction procedures for heavy metal partitioning in mine tailings. Chemosphere 78, 1393-1402.

Anju, M., Banerjee, D. K., 2011. Multivariate statistical analysis of heavy metals in soils of a Pb-Zn mining area, India. Environ Monit Assess 184, 4191-4206.

Arai, Y., 2011. Arsenic and Antimony. In: Trace elements in soils. Wiley Press, p. 386.

Arias, R., Barona, A., Berastegi, G. I., Aranguiz, I., Elias, A., 2008. Assessment of metal contamination in dredged sediments using fractionation and self-organizing maps. J Hazard Mater 151, 78-85.

Banerjee, A. D. K., 2003. Heavy metal levels and solid phase speciation in street dusts of Delhi, India. Environ Pollut 123, 95-105.

Boularbah, A., Schwartz, C., Bitton, G., Morel, J. L., 2006. Heavy metal contamination from mining sites in South Morocco. 1. Use of a biotest to assess metal toxicity of tailings and soils. Chemosphere 63, 802-810. 
Chen, T. B., Zheng, Y. M., Lei, M., Huang, Z. C., Wu, H. T., Chen, H., Fan, K. K., Yu, K., Wu, X., Tian, Q. Z., 2005. Assessment of heavy metal pollution in surface soils of urban parks in Beijing, China. Chemosphere 60, 542-551.

Chopin, E. I. B., Alloway, B. J., 2007. Distribution and mobility of trace elements in soils and vegetation around the mining and smelting areas of Tharsis, Ríotinto and Huelva, Iberian Pyrite Belt, SW Spain. Water Air Soil Poll 182, 245-261.

Cui, Y., Xin, D., 2011. Soil heavy metal and wheat phytotoxicity in the vicinity of an abandoned lead-zinc mine in Shangyu City, eastern China. Environ Earth Sci 62, 257-264.

Desaules, A., 2012. Critical evaluation of soil contamination assessment methods for trace metals. Sci Total Environ 426, 120-131.

Du, P., Xue, N., Liu, L., Li, F., 2008. Distribution of Cd, Pb, Zn, and $\mathrm{Cu}$ and their chemical speciations in soils from a peri-smelter area in northeast China. Environ Geol 55, 205-213.

Favas, P. J. C., Pratas, J., Gomez, M. E. P., Cala, V., 2011. Selective chemical extraction of heavy metals in tailings and soils contaminated by mining activity. $\mathbf{J}$ Geochem Explor 111, 160-171.

Fernandez-Caliani, J. C., Barba-Brioso, C., Gonzalez, I., Galan, E., 2009. Heavy metal pollution in soils around the abandoned mine sites of the Iberian Pyrite Belt (southwest Spain). Water Air Soil Poll 200, 211-226.

Ferreira da Silva, E., Zhang, C., Serrano Pinto, L., Patinha, C., Reis, P., 2004. Hazard assessment on arsenic and lead in soils of Castromil gold mining area, Portugal. Appl Geochem 19, 887-898.

Forghani, G., Moore, F., Lee, S., Qishlaqi, A., 2009. Geochemistry and speciation of metals in sediments of the Maharlu saline lake, Shiraz, SW Iran. Environ Earth Sci 59, 173-184.

Ghazban, F., Nc Nutt, R. H., Schwarcz, H. P., 1994. Genesis of sediment-hosted Zn-PbBa deposits in the Irankuh district, West-Central Iran. Econ Geol 89, 1262-1278.

Ghrefat, H. A., Uusuf, N., Jamarh, A., Nazzal, J., 2012. Fractionation and risk assessment of heavy metals in soil samples collected along Zerqa River, Jordan. Environ Earth Sci 66, 199-208. 
Hang, X., Wang H., Zhou, J., Du, C., Chen, X., 2009. Characteristics and accumulation of heavy metals in sediments originated from an electroplating plant. $\mathrm{J}$ Hazard Mater 163, 922-930.

Jeffery, P. G., Hutchinson, P., 1983. Chemical methods of rock analysis. Third edition, Pergamon. P. 379.

Kabala C., Singh, B. R., 2001. Fractionation and mobility of copper, lead and zinc in soil profiles in the vicinity of a copper smelter. J Environ Qual 30, 485-492.

Kabata-Pendias, A., 2011. Trace Elements in Soils and Plants. 4th ed. CRC Press, Boca Raton, FL. P. 413

Korfali, S. I., Davies, B. E., 2004. Speciation of metals in sediment and water in a river underlain by limestone: role of carbonate species for purification capacity of rivers. Adv Environ Res 8, 599-612.

Kreidie, N., Armiento, G., Cibin, G., Cinque, G., Crovato, C., Nardi, E., Pacifico, R., Cremisini, C., Mottana, A., 2011. An integrated geochemical and mineralogical approach for the evaluation of arsenic mobility in mining soils. J Soil Sediment 11, $37-52$.

Lasheen, M. R., Ammar, N. S., 2009. Assessment of metals speciation in sewage sludge and stabilized sludge from different wastewater treatment plants, Greater Cairo, Egypt. J Hazard Mater 164, 740-749.

Li, X., Feng, L., 2012. Geostatistical analyses and fractionation of heavy metals in urban soil from industrial district in Weinan, NW China. Environ Earth Sci 67, 2129-2140.

Li, Zh., Feng, X., Li, G., Bi, X., Sun, G., Zhu, J.,Qin, H., Wang, J., 2011. Mercury and other metal and metalloid soil contamination near a $\mathrm{Pb} / \mathrm{Zn}$ smelter in east Hunan province, China. Appl Geochem 26, 160-166.

Lu, S. G., Bai, S. Q., 2010. Contamination and potential mobility assessment of heavy metals in urban soils of Hangzhou, China: relationship with different land uses. Environ Earth Sci 60, 1481-1490.

Ma, Y., Hooda, P. S., 2011. Chromium, nickel and cobalt. In Trace elements in soils. Wiley Press. P. 462.

Ma, L. Q., Rao, G. N., 1997. Chemical fractionation of cadmium, copper, nickel, and zinc in contaminated soils. J Environ Qual 26, 259-264. 
Mahanta, M. J., Bhattacharyya, K. G., 2011. Total concentrations, fractionation and mobility of heavy metals in soils of urban area of Guwahati, India. Environ Monit Assess 173, 221-240.

Martinez-Martinez, S., Acosta, J. A., Faz Cano, A., Carmona, D. M., Zornoza, R., Cerda, C., 2013. Assessment of the lead and zinc contents in natural soils and tailing ponds from the Cartagena-La Union mining district, SE Spain. J Geochem Explor $124,166-175$.

Müller, G., 1969. Index of geoaccumulation in the sediments of the Rhine River. GEO J 2, 108-118.

Naji, A., Ismail, A., Ismail, A. R., 2010. Chemical speciation and contamination assessment of $\mathrm{Zn}$ and $\mathrm{Cd}$ by sequential extraction in surface sediment of Klang River. Malaysia. Microchem J 95, 285-292.

Nannoni, F., Protano, G., Riccobono, F., 2011. Fractionation and geochemical mobility of heavy elements in soils of a mining area in northern Kosovo. Geoderma 161, 6373.

Ozkan, S, Ipekoglu B., 2002. Investigation of environmental impacts of tailings dams. Environ Manage Health 13, 242-248.

Siegel, F., 2002. Environmental geochemistry of potentially toxic metals. SpringerVerlag, Berlin, Heidelberg, P. 218.

Taylor, M. P., Kesterton, R. G. H., 2002. Heavy metal contamination of an arid river environment: Grubon River, Namibia. Geomorphology 42, 311-327.

Taylor, S. R., McLennan, S. M., 1985. The continental Crust: Its composition and evolution. Blackwell Scientific Publication, Carlton, P. 312.

Tessier, A., Campbell, P. G. C., Bisson, M., 1979. Sequential extraction procedure for the speciation of particulate trace metals. Anal Chem 51, 844-851.

Tomlinson, D. L., Wilson, J. G., Harris, C. R., Jeffrey, D. W., 1980. Problems in the assessments of heavy metal levels in estuaries and formation of a pollution index. Helgoland Meeresunters 33, 566-575.

Turekian, K. K., Wedepohl, K. H., 1961. Distribution of elements in some major units of the earth's crust. Geol Soc Am Bull 72, 175-192.

US Department of Agriculture (USDA), 2003. Soil Survey Laboratory Methods Manual; (Soil Survey Laboratory Investigations Report 42, ver 3.0). Washington, DC. 
US EPA, 1998. Test methods for evaluating solid waste, Method 9045D. EPA, Washington, D.C.

Wang, X., He, M., Xie, J., Xi, J., Lu, X., 2010. Heavy metal pollution of the world largest antimony mine affected agricultural soils in Hunan province (China). J Soil Sediment 10, 827-837.

Yan, C., Li, Q., Zhang, X., Li, G., 2010. Mobility and ecological risk assessment of heavy metals in surface sediments of Xiamen Bay and its adjacent areas, China. Environ Earth Sci 60, 1469-1479.

\section{Figure Captions}

Fig. 1 Geological map of the Irankuh district and location of the sampling sites.

Fig. 2 The relationship between (a) CEC and soil organic matter, (b) CEC and the clay fraction content and (c) carbonate content and $\mathrm{pH}$.

Fig. 3 Mean concentration of elements in the studied soil samples and worldwide uncontaminated soils values (Kabata-Pendias 2011)

Fig. 4 Frequency distribution of total concentrations of $\mathrm{As}, \mathrm{Cd}, \mathrm{Cr}, \mathrm{Cu}, \mathrm{Ni}, \mathrm{Pb}$, and $\mathrm{Zn}$ in soil samples.

Fig. 5 Concentration of studied elements in the tailing sample compared with worldwide uncontaminated soil values (Kabata-Pendias 2011) and crustal average values (Taylor and McLennan 1985).

Fig. 6 Percentage of samples in Müller class, using average shale composition as reference material.

Fig. 7 Speciation of PTEs in soil samples of Irankuh district.

Fig. 8 The PTEs mobility factors defined as the sum of first two fractions divided by the sum of all five fractions (see the text).

Fig. 9 The percent of PTEs in none-residual and residual phases of studied soils. 
Table 1- General characteristics of agricultural soils, minesoils and tailing samples

\begin{tabular}{|c|c|c|c|c|c|c|c|c|}
\hline & $\begin{array}{l}\text { Sampling } \\
\text { site }\end{array}$ & pH & $\begin{array}{r}\mathrm{CaCO}_{3} \\
(\%)\end{array}$ & $\begin{array}{l}\text { OM } \\
(\%)\end{array}$ & $\begin{array}{r}\text { Sand } \\
(\%)\end{array}$ & $\begin{array}{l}\text { Silt } \\
(\%)\end{array}$ & $\begin{array}{r}\text { Clay } \\
(\%)\end{array}$ & $\begin{array}{c}\text { CEC } \\
(\mathrm{meq} / \mathbf{1 0 0 g})\end{array}$ \\
\hline \multicolumn{9}{|l|}{ Agricultural } \\
\hline \multirow[t]{23}{*}{ soils } & A1 & 7.9 & 42 & 0.8 & 66 & 21.3 & 12.7 & 12.2 \\
\hline & $\mathrm{A} 2$ & 7.7 & 44.5 & 0.9 & 46 & 25.3 & 28.7 & 18.1 \\
\hline & A3 & 7.6 & 40.5 & 0.8 & 46 & 33.3 & 20.7 & 22.2 \\
\hline & A4 & 8.2 & 48.5 & 0.3 & 72 & 11.3 & 16.7 & 15.5 \\
\hline & A5 & 7.6 & 48.5 & 0.8 & 48 & 27.3 & 24.7 & 18.3 \\
\hline & A6 & 7.7 & 47 & 0.7 & 35.3 & 31.8 & 32.9 & 19.6 \\
\hline & A7 & 8.4 & 43.5 & 0.6 & 11.3 & 33.8 & 54.9 & 15.2 \\
\hline & A8 & 7.8 & 46 & 1 & 40.6 & 39.9 & 19.5 & 14.4 \\
\hline & A9 & 7.8 & 41.5 & 0.9 & 34.8 & 36.8 & 28.4 & 18 \\
\hline & A10 & 7.7 & 45 & 0.9 & 21 & 52.5 & 26.5 & 16.1 \\
\hline & A11 & 7.5 & 47.5 & 0.9 & 58.4 & 16.3 & 25.3 & 16.5 \\
\hline & A12 & 7.6 & 43 & 0.8 & 48.2 & 27 & 24.8 & 15.3 \\
\hline & A13 & 7.6 & 35 & 0.6 & 28.5 & 42.6 & 28.9 & 15.4 \\
\hline & A14 & 7.6 & 40.5 & 0.8 & 32.3 & 39.2 & 28.5 & 15.2 \\
\hline & A15 & 7.9 & 46 & 0.8 & 57.2 & 28 & 14.8 & 11.7 \\
\hline & A16 & 7.9 & 44 & 0.8 & 39.2 & 45 & 15.8 & 14.5 \\
\hline & A17 & 8.2 & 43 & 0.8 & 38 & 40.8 & 21.2 & 13.5 \\
\hline & A18 & 8.4 & 40 & 0.8 & 43 & 38.5 & 18.5 & 11.2 \\
\hline & A19 & 8.5 & 36 & 0.9 & 43.7 & 35 & 21.3 & 14.9 \\
\hline & A20 & 8.5 & 21 & 0.6 & 68 & 14.2 & 17.8 & 13 \\
\hline & Average & 7.9 & 42.2 & 0.8 & 43.9 & 32 & 24.1 & 15.5 \\
\hline & Min. & 7.5 & 21 & 0.3 & 11.3 & 11.3 & 12.7 & 11.2 \\
\hline & Max. & 8.5 & 48.5 & 1 & 72 & 52.5 & 54.9 & 22.2 \\
\hline \multicolumn{9}{|l|}{ Minesoils } \\
\hline & M1 & 8 & 41.5 & 0.02 & 32 & 39.3 & 28.7 & 10.9 \\
\hline & M2 & 8.3 & 44 & 1.1 & 65.3 & 15.8 & 18.9 & 16.7 \\
\hline & M3 & 8.4 & 33.5 & 0.1 & 66 & 21.3 & 12.7 & 16.9 \\
\hline & M4 & 8.4 & 41.5 & 0.2 & 58 & 9.3 & 32.7 & 10.2 \\
\hline & M5 & 8.3 & 45 & 0.2 & 43.3 & 35.8 & 20.9 & 13.1 \\
\hline & M6 & 8.5 & 45.5 & 0.3 & 44 & 37.3 & 18.7 & 13.8 \\
\hline & M7 & 8.5 & 42 & 0.3 & 14 & 61.3 & 24.7 & 10.3 \\
\hline & M8 & 8.4 & 38 & 0.2 & 62.2 & 21.1 & 16.7 & 13.6 \\
\hline & Average & 8.3 & 41.4 & 0.3 & 48.1 & 30.2 & 21.8 & 13.2 \\
\hline & Min. & 8 & 33.5 & 0.02 & 14 & 9.3 & 12.7 & 10.2 \\
\hline & Max. & 8.5 & 45.5 & 1.1 & 66 & 61.3 & 32.7 & 16.9 \\
\hline \multicolumn{9}{|l|}{ Tailing } \\
\hline & & 7.9 & 42 & 0.25 & 26 & 50.3 & 23.7 & 12.8 \\
\hline
\end{tabular}


Table 2- Minerals identified by XRD analysis of selected soils and tailing samples

\begin{tabular}{lll}
\hline A16 & A18 & Tailing \\
\hline Orthoclase & Nitratine & Dolomite \\
Calcite & Quartz & Quartz \\
Quartz & Heulandite & Muscovite \\
Montmorillonite & Albite & Illite \\
Kaolinite & Clinochlore & Bassanite \\
Dolomite & Illite & Albite \\
Illite & Calcite & \\
\hline
\end{tabular}


Table 3- Total element concentration $\left(\mathrm{mg} \mathrm{kg}^{-1}\right)$ in 28 soil samples of the study area.

\begin{tabular}{|c|c|c|c|c|c|c|c|c|c|c|c|c|c|}
\hline & $\begin{array}{c}\text { Sampling } \\
\text { site }\end{array}$ & Al & As & Cd & $\mathrm{Cr}$ & $\mathbf{C u}$ & $\mathbf{N i}$ & $\mathbf{P b}$ & Sc & $\mathbf{T i}$ & $\mathbf{V}$ & Zn & $\mathbf{Z r}$ \\
\hline \multicolumn{14}{|l|}{$\begin{array}{l}\text { Agricultural } \\
\text { soils }\end{array}$} \\
\hline & A1 & 32631 & 34.2 & 3.9 & 62 & 61 & 37 & 284 & 6.8 & 1809 & 56 & 1173 & 88 \\
\hline & A2 & 28154 & 32.4 & 4.1 & 52 & 35 & 33 & 254 & 5.9 & 1585 & 49 & 1007 & 77 \\
\hline & A3 & 32643 & 19.9 & 1.7 & 31 & 37 & 32 & 174 & 6.5 & 1753 & 53 & 709 & 81 \\
\hline & A4 & 39180 & 17.7 & 1.2 & 16 & 17 & 29 & 129 & 7.5 & 2122 & 61 & 342 & 94 \\
\hline & A5 & 27894 & 13.1 & 2.1 & 29 & 29 & 32 & 385 & 5.7 & 1622 & 48 & 1247 & 66 \\
\hline & A6 & 29554 & 57.1 & 8.5 & 35 & 49 & 34 & 3451 & 6 & 1595 & 50 & 9907 & 71 \\
\hline & A7 & 34185 & 10.3 & 1.7 & 47 & 25 & 42 & 210 & 7.1 & 1938 & 59 & 673 & 81 \\
\hline & A8 & 71608 & 8.8 & 0.4 & 103 & 39 & 68 & 33 & 15.6 & 3357 & 107 & 171 & 163 \\
\hline & A9 & 62980 & 9.7 & 0.5 & 109 & 35 & 67 & 41 & 14.4 & 3169 & 97 & 147 & 154 \\
\hline & A10 & 55053 & 8.1 & 0.8 & 97 & 30 & 51 & 77 & 12.5 & 2759 & 78 & 342 & 126 \\
\hline & A11 & 63297 & 11.8 & 1.4 & 87 & 26 & 44 & 181 & 13.1 & 2804 & 76 & 902 & 128 \\
\hline & A12 & 64033 & 7.3 & 0.5 & 104 & 30 & 68 & 39 & 14.7 & 3098 & 101 & 179 & 157 \\
\hline & A13 & 63239 & 5.5 & 0.4 & 86 & 32 & 56 & 31 & 13.7 & 3024 & 87 & 174 & 126 \\
\hline & A14 & 67767 & 9.9 & 0.5 & 90 & 30 & 61 & 29 & 14.9 & 3330 & 99 & 154 & 158 \\
\hline & A15 & 60164 & 7.8 & 0.7 & 96 & 35 & 60 & 39 & 13.4 & 2978 & 89 & 122 & 123 \\
\hline & A16 & 70920 & 9.3 & 0.4 & 100 & 45 & 67 & 43 & 15.2 & 3318 & 100 & 134 & 161 \\
\hline & A17 & 65431 & 5.6 & 0.3 & 79 & 30 & 59 & 41 & 14.3 & 3061 & 93 & 133 & 143 \\
\hline & A18 & 63532 & 9.5 & 0.8 & 104 & 37 & 61 & 28 & 13.6 & 2918 & 90 & 160 & 138 \\
\hline & A19 & 59489 & 6.6 & 0.2 & 75 & 39 & 57 & 23 & 13.7 & 2827 & 86 & 94 & 145 \\
\hline & $\mathrm{A} 20$ & 60548 & 5.5 & 0.2 & 79 & 30 & 56 & 22 & 13.8 & 2947 & 86 & 106 & 140 \\
\hline \multicolumn{14}{|l|}{ Minesoils } \\
\hline & M1 & 41707 & 17.4 & 1.8 & 49 & 24 & 43 & 470 & 8.2 & 2611 & 70 & 1111 & 105 \\
\hline & M2 & 22681 & 254 & 55.1 & 55 & 60 & 46 & 6239 & 4.6 & 1292 & 43 & 26803 & 62 \\
\hline & M3 & 45073 & 64.2 & 16.4 & 56 & 26 & 36 & 3953 & 8.8 & 2533 & 72 & 48899 & 129 \\
\hline & M4 & 34990 & 13 & 1.2 & 56 & 23 & 45 & 142 & 7.2 & 2201 & 57 & 599 & 105 \\
\hline & M5 & 32282 & 61.9 & 14.5 & 64 & 44 & 42 & 2039 & 6.8 & 1996 & 57 & 9446 & 98 \\
\hline & M6 & 29411 & 127.8 & 31 & 48 & 31 & 48 & 1177 & 6 & 1628 & 53 & 6974 & 84 \\
\hline & M7 & 43552 & 12.9 & 1.4 & 54 & 32 & 46 & 137 & 9.1 & 2791 & 72 & 516 & 113 \\
\hline & M8 & 31607 & 21.6 & 1.4 & 54 & 25 & 41 & 255 & 6.6 & 1803 & 56 & 654 & 84 \\
\hline \multicolumn{2}{|l|}{ Average } & 47628.8 & 30.8 & 5.5 & 68.5 & 34.1 & 48.6 & 711.6 & 10.2 & 2459.6 & 73 & 4031.4 & 114.3 \\
\hline \multicolumn{2}{|l|}{ Min. } & 22681 & 5.5 & 0.2 & 16 & 17 & 29 & 22 & 4.6 & 1292 & 43 & 94 & 62 \\
\hline & 71608 & 254 & 55.1 & 109 & 61 & 68 & 6239 & 15.6 & 3357 & 107 & 48899 & 163 \\
\hline \multicolumn{2}{|l|}{$\begin{array}{l}\text { S. D. } \\
\text { C. V. }\end{array}$} & 16179.7 & 51.2 & 11.8 & 26.3 & 10.3 & 12.3 & 1473 & 3.8 & 649.2 & 19.5 & 10361.9 & 31.9 \\
\hline \multirow{2}{*}{\multicolumn{2}{|c|}{ Skewness }} & 0.3 & 1.7 & 2.2 & 0.4 & 0.3 & 0.3 & 2.1 & 0.4 & 0.3 & 0.3 & 2.6 & 0.3 \\
\hline \multirow{2}{*}{\multicolumn{2}{|c|}{ Kurtosis }} & 0.04 & 3.6 & 3.4 & -0.1 & 1.2 & 0.1 & 2.8 & 0.07 & -0.3 & 0.2 & 3.6 & 0 \\
\hline & & -1.7 & 14 & 12.1 & -1 & 1.6 & -1.2 & 7.5 & -1.8 & -1.5 & -1.4 & 14 & -1.3 \\
\hline \multicolumn{2}{|l|}{ Global soil average } & 67000 & 11.3 & 0.6 & 84 & 26 & 34 & 29 & 10 & 5000 & 105 & 60 & 345 \\
\hline \multicolumn{2}{|l|}{ Tailing } & 9984.5 & 96.1 & 17.9 & 7 & 74 & 11.5 & 2835 & 1.9 & 544 & 20.5 & 6689.5 & 28 \\
\hline
\end{tabular}


Table 4- Degree of pollution by PTEs according to $\mathrm{I}_{\text {geo }}$, Pi and CPI

\begin{tabular}{|c|c|c|c|}
\hline Index & Author & Value & Degree of pollution \\
\hline \multirow[t]{7}{*}{$\mathrm{I}_{\mathrm{geo}}$} & Muller (1968) & $\mathrm{I}_{\mathrm{geo}} \leq 0$ & Unpolluted \\
\hline & & $0<\mathrm{I}_{\mathrm{geo}} \leq 1$ & Unpolluted to moderately polluted \\
\hline & & $1<\mathrm{I}_{\mathrm{geo}} \leq 2$ & Moderately polluted \\
\hline & & $2<\mathrm{I}_{\mathrm{geo}} \leq 3$ & Moderate to strongly polluted \\
\hline & & $3<\mathrm{I}_{\text {geo }} \leq 4$ & Strongly polluted \\
\hline & & $4<\mathrm{I}_{\mathrm{geo}} \leq 5$ & Strongly to extremely polluted \\
\hline & & $\mathrm{I}_{\mathrm{geo}}>5$ & Extremely polluted \\
\hline \multirow[t]{5}{*}{$\mathrm{P}_{\mathrm{i}}$} & Li et al. (2011) & $\mathrm{Ci}<$ background & Excellent \\
\hline & & $\mathrm{Pi}<1$ & Clean \\
\hline & & $1 \leq \mathrm{Pi}<2$ & Slightly polluted \\
\hline & & $2 \leq \mathrm{Pi}<3$ & Moderately polluted \\
\hline & & $\mathrm{Pi} \geq 3$ & Heavily polluted \\
\hline \multirow[t]{7}{*}{ CPI } & Abrahim and Parker & $\mathrm{CPI} \leq 1.5$ & Nil to very low \\
\hline & (2008) & $1.5<\mathrm{CPI} \leq 2$ & Low \\
\hline & & $2<\mathrm{CPI} \leq 4$ & Moderate \\
\hline & & $4<\mathrm{CPI} \leq 8$ & High \\
\hline & & $8<\mathrm{CPI} \leq 16$ & Very high \\
\hline & & $16<\mathrm{CPI} \leq 32$ & Extremely high \\
\hline & & $\mathrm{CPI}>32$ & Ultra high \\
\hline
\end{tabular}


Table 5- The result of single-factor assessment (pi), CPI and PLI for tailing and soil samples of the study area.

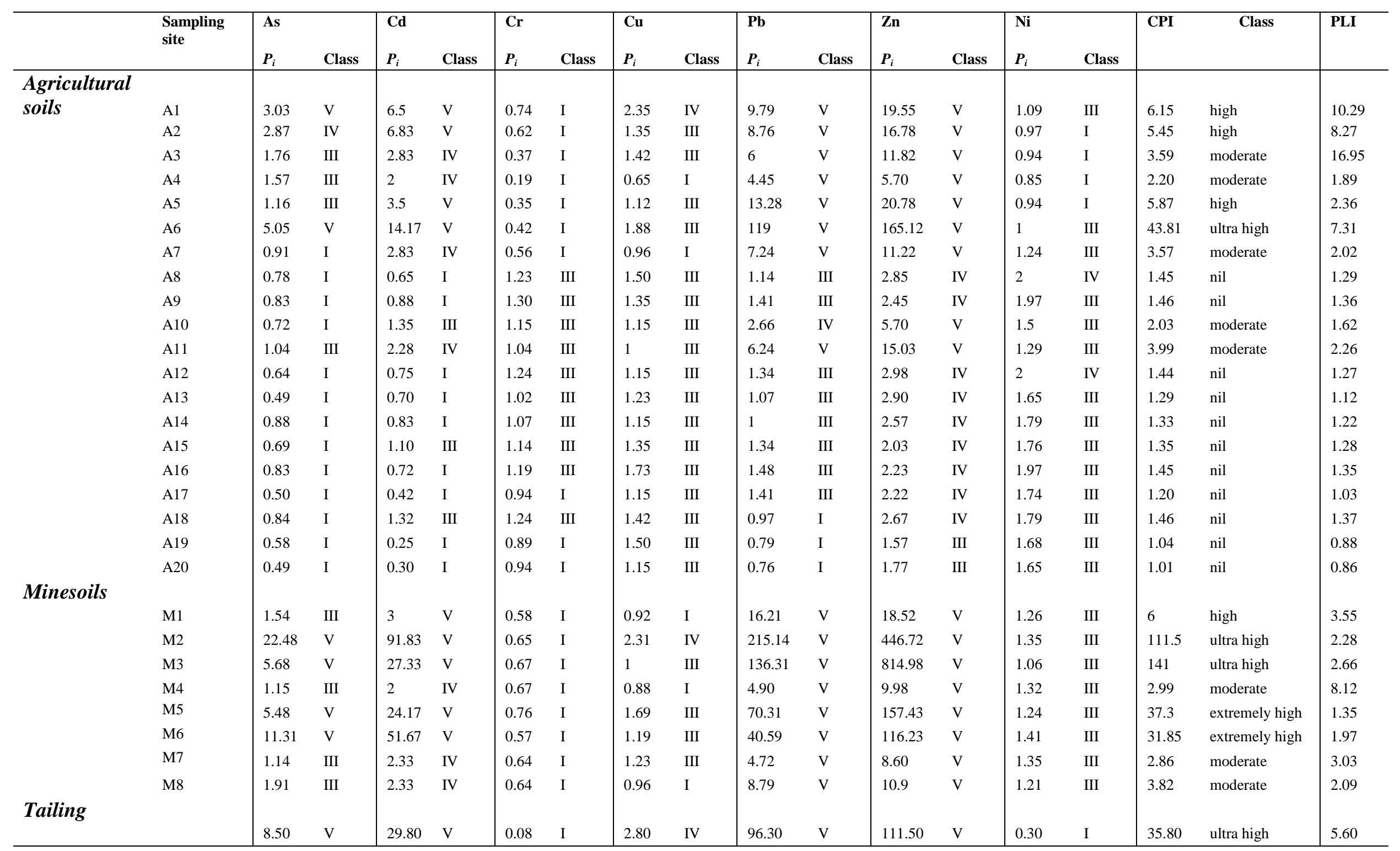


Table 6- Pearson's rank correlation matrix of studied elements in the soil samples.

\begin{tabular}{|c|c|c|c|c|c|c|c|c|c|c|c|c|c|c|}
\hline & Al & As & Cd & $\mathrm{Cr}$ & $\mathrm{Cu}$ & $\mathrm{Fe}$ & Mn & $\mathbf{N i}$ & $\mathbf{P b}$ & Sc & $\mathbf{T i}$ & $\mathbf{V}$ & $\mathbf{Z n}$ & $\mathbf{Z r}$ \\
\hline Al & 1 & & & & & & & & & & & & & \\
\hline As & $-.772^{* *}$ & 1 & & & & & & & & & & & & \\
\hline Cd & $-.789^{* *}$ & $.964^{* *}$ & 1 & & & & & & & & & & & \\
\hline $\mathrm{Cr}$ & $.728^{* *}$ & $-.433^{*}$ & $-.442^{*}$ & 1 & & & & & & & & & & \\
\hline $\mathrm{Cu}$ & -.134 & .347 & .263 & .286 & 1 & & & & & & & & & \\
\hline $\mathrm{Fe}$ & .261 & -.181 & -.176 & .328 & .217 & 1 & & & & & & & & \\
\hline Mn & $-.555^{* *}$ & $.637^{* *}$ & $.612^{* * *}$ & -.277 & .294 & -.220 & 1 & & & & & & & \\
\hline $\mathbf{N i}$ & $.788^{* *}$ & $-.517^{* *}$ & $-.570^{* * *}$ & $.879^{* * *}$ & .168 & .272 & -.315 & 1 & & & & & & \\
\hline $\mathbf{P b}$ & $-.796^{* *}$ & $.914^{* *}$ & $.945^{* *}$ & $-.524^{* *}$ & .197 & -.255 & $.562^{* * *}$ & $-.649^{* *}$ & 1 & & & & & \\
\hline Sc & $.995^{* *}$ & $-.782^{* *}$ & $-.804^{* * *}$ & $.765^{* *}$ & -.095 & .289 & $-.567^{* * *}$ & $.820^{* *}$ & $-.815^{* * *}$ & 1 & & & & \\
\hline $\mathbf{T i}$ & $.972^{* *}$ & $-.773^{* *}$ & $-.773^{* * *}$ & $.698^{* * *}$ & -.210 & .185 & $-.518^{* * *}$ & $.765^{* *}$ & $-.765^{* * *}$ & $.963^{* * *}$ & 1 & & & \\
\hline $\mathbf{v}$ & $.982^{* *}$ & $-.739^{* *}$ & $-.766^{* * *}$ & $.750^{* * *}$ & -.101 & .229 & $-.541^{* *}$ & $.840^{* *}$ & $-.781^{* * *}$ & $.982^{* * *}$ & $.974^{* * *}$ & 1 & & \\
\hline $\mathbf{Z n}$ & $-.727^{* *}$ & $.914^{* *}$ & $.950^{* * *}$ & $-.442^{*}$ & .204 & -.194 & $.540^{* * *}$ & $-.595^{* *}$ & $.982^{* *}$ & $-.748^{* *}$ & $-.702^{* *}$ & $-.715^{* * *}$ & 1 & \\
\hline $\mathrm{Zr}$ & $.959^{* *}$ & $-.677^{* *}$ & $-.714^{* * *}$ & $.750^{* * *}$ & -.128 & .239 & $-.482^{* * *}$ & $.799^{* * *}$ & $-.727^{* * *}$ & $.957^{* * *}$ & $.967^{* * *}$ & $.970^{* * *}$ & $-.642^{* * *}$ & 1 \\
\hline
\end{tabular}




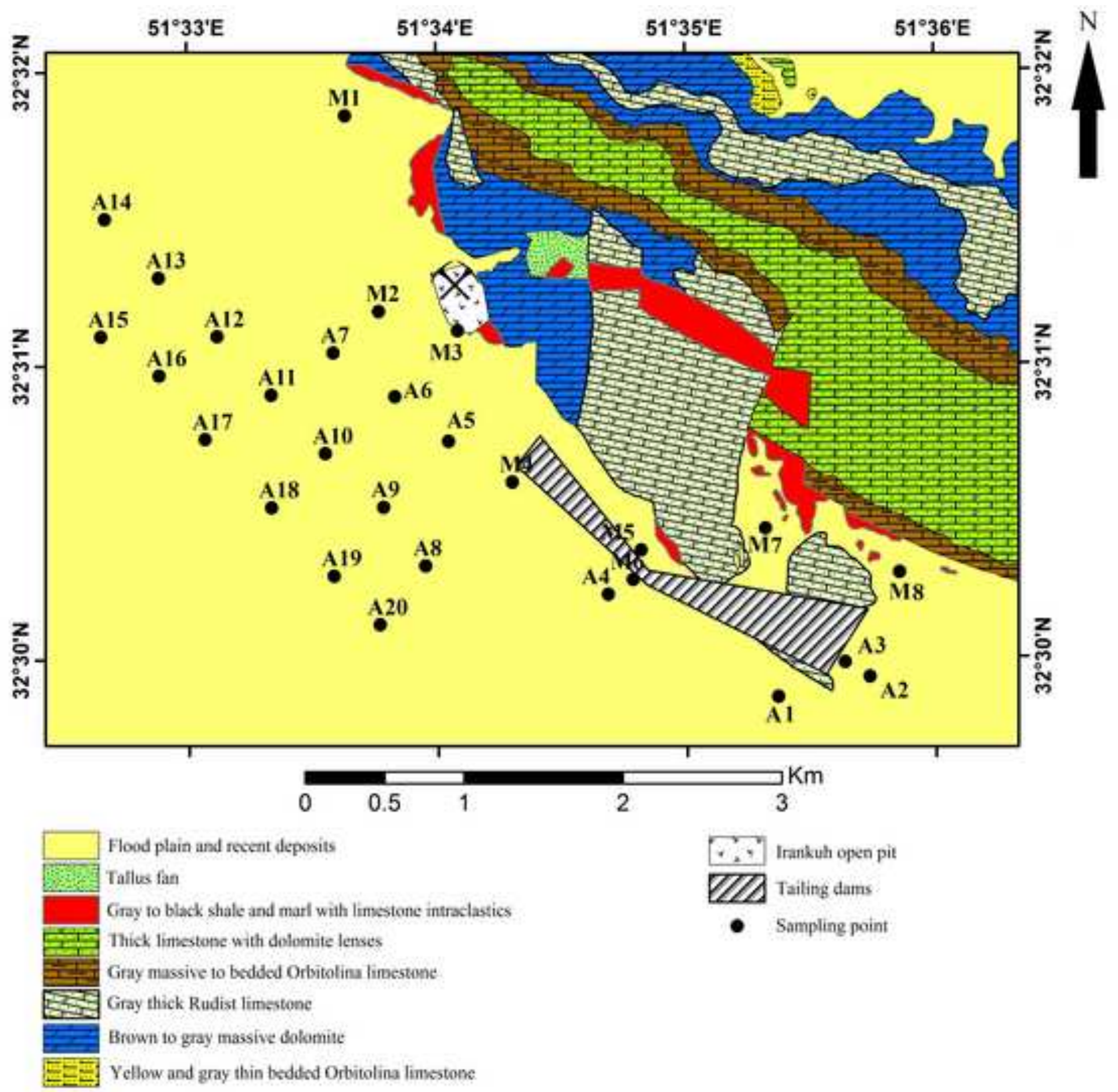




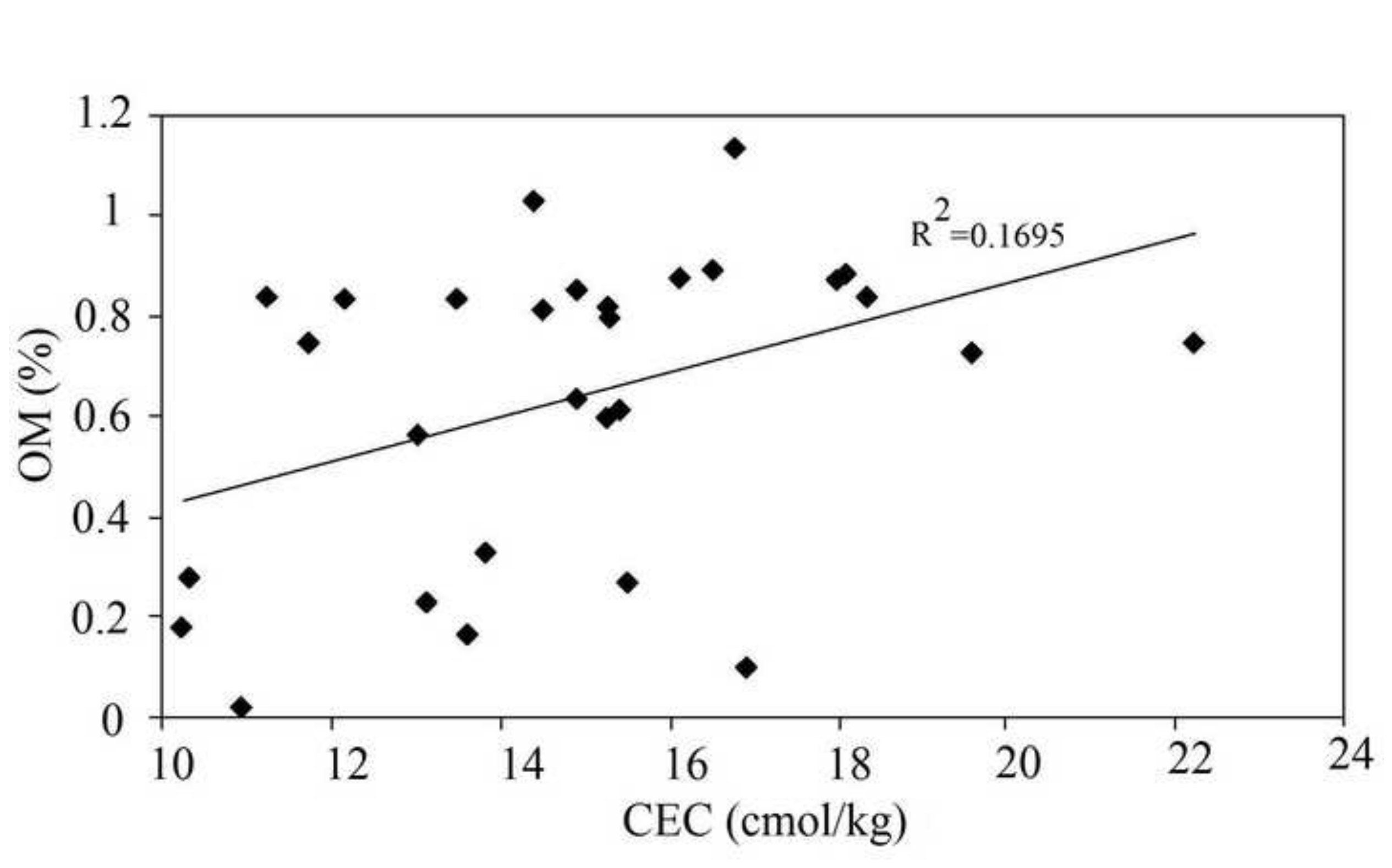




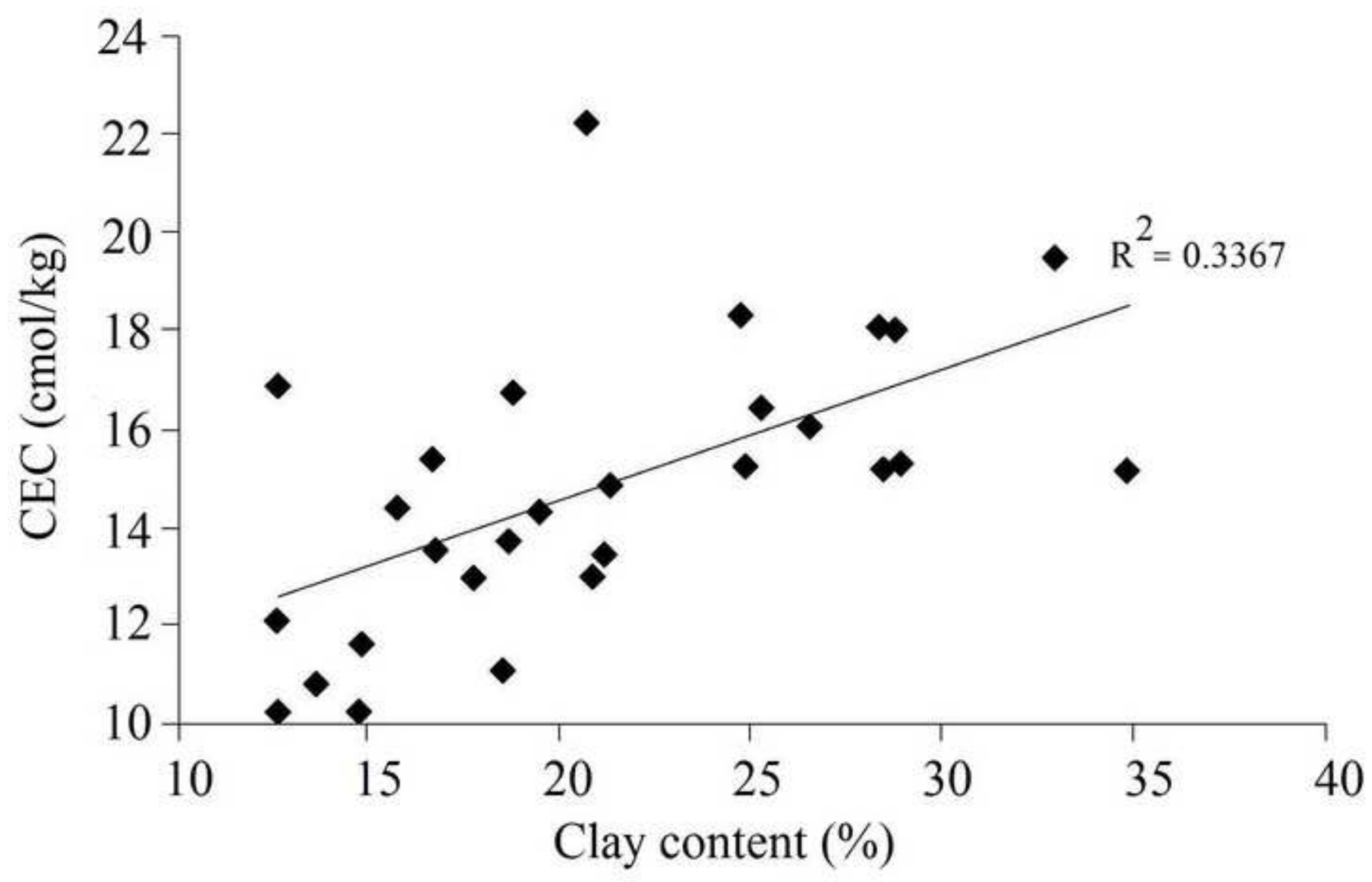




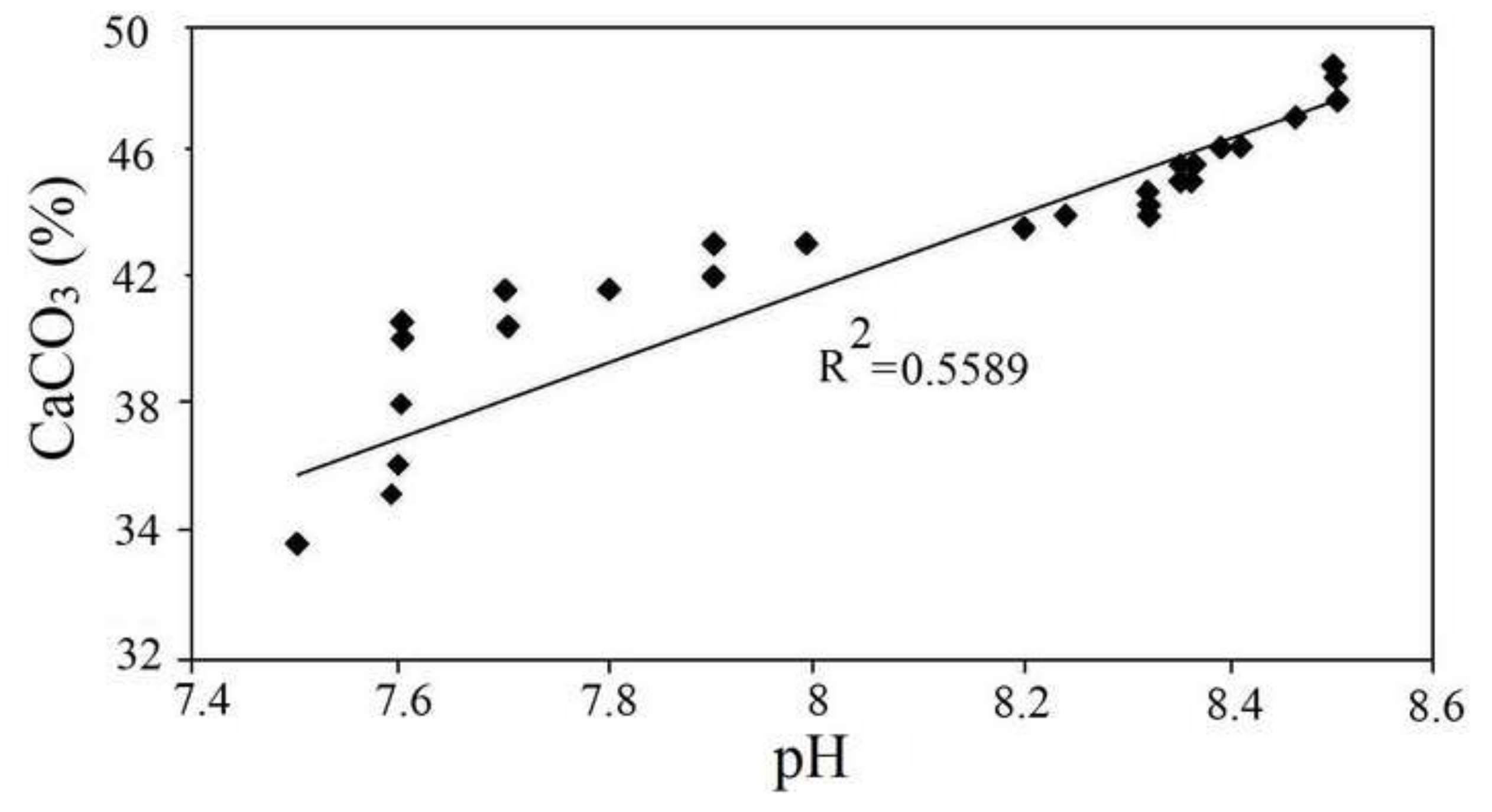




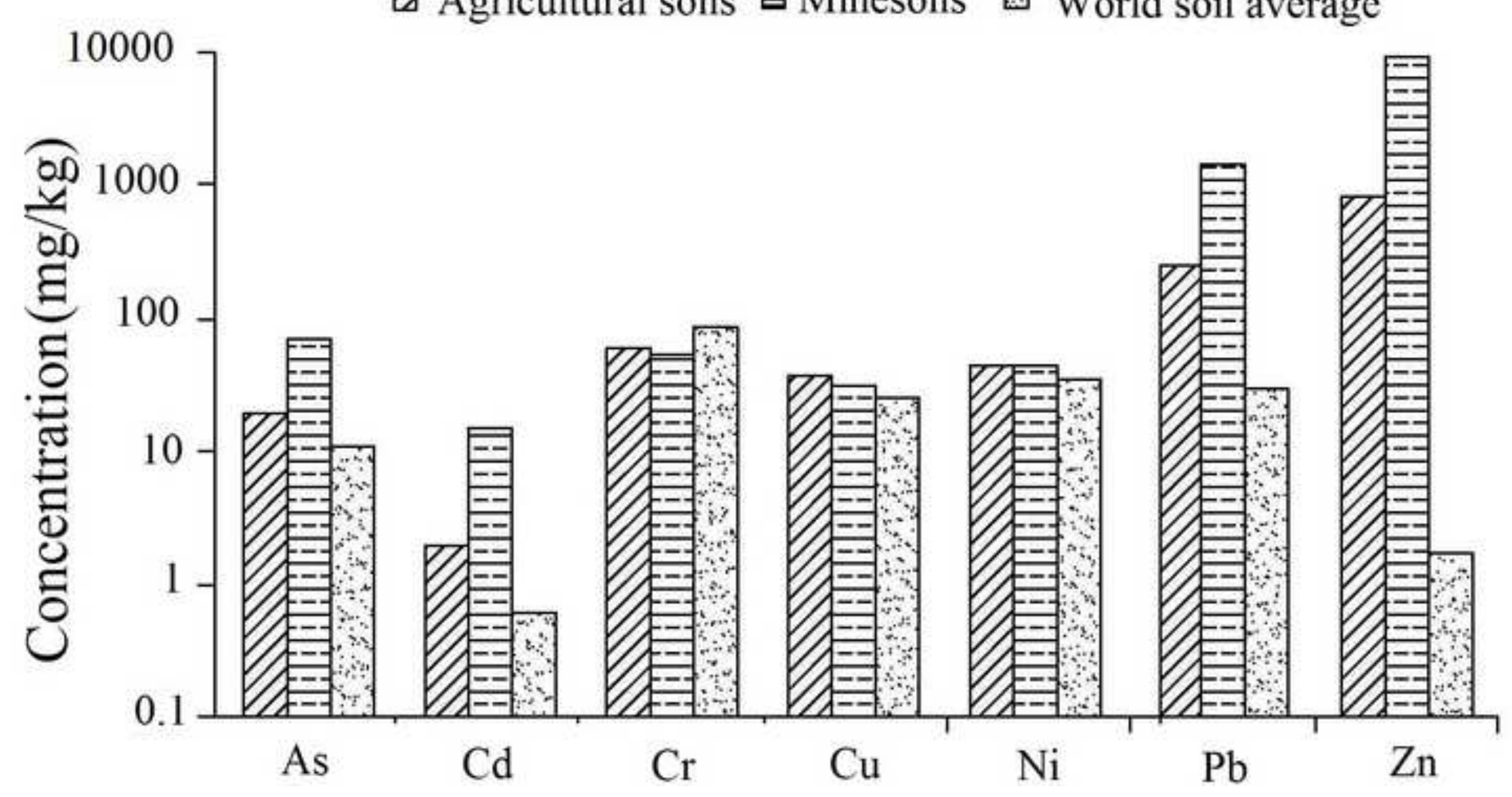



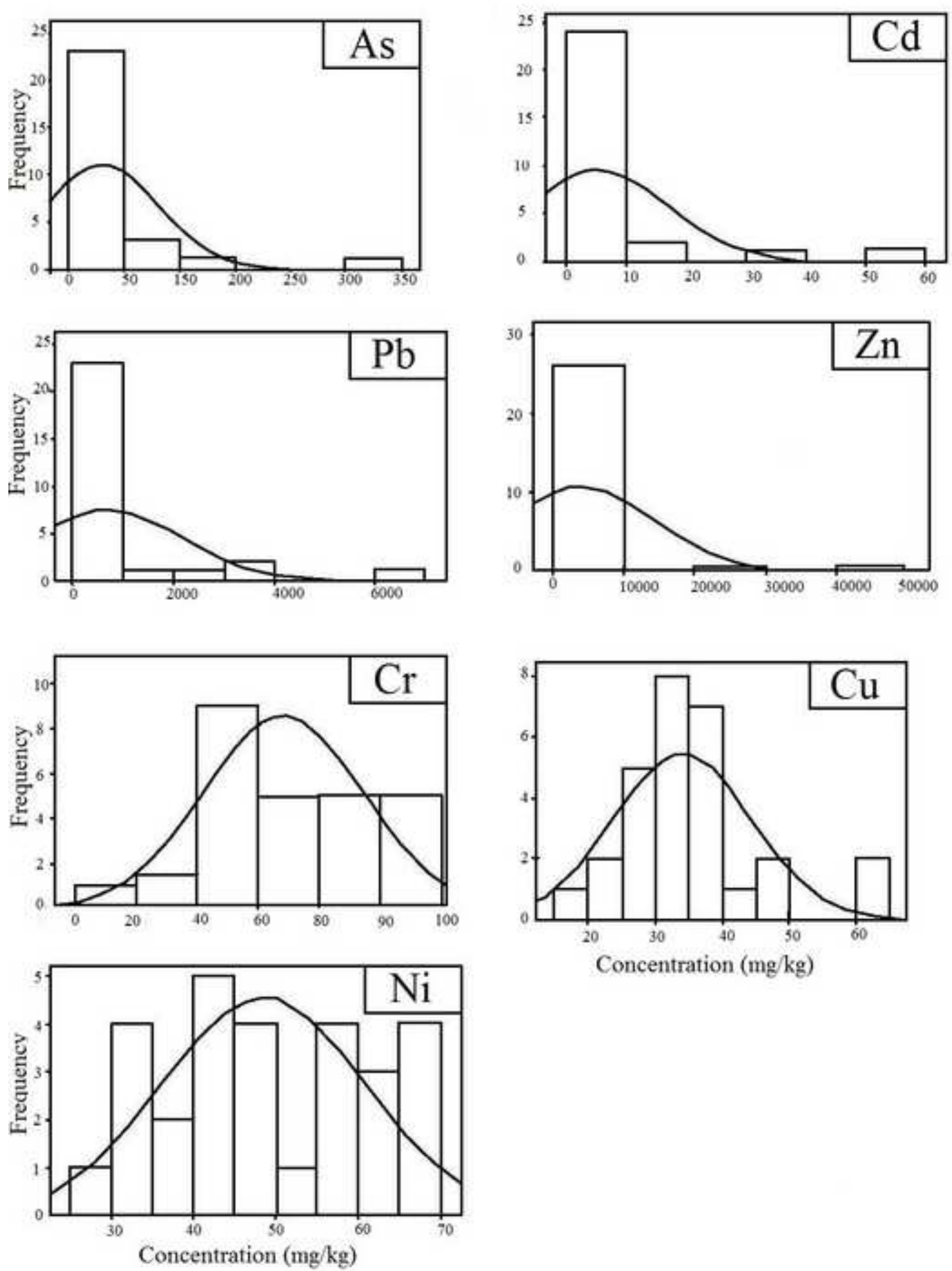


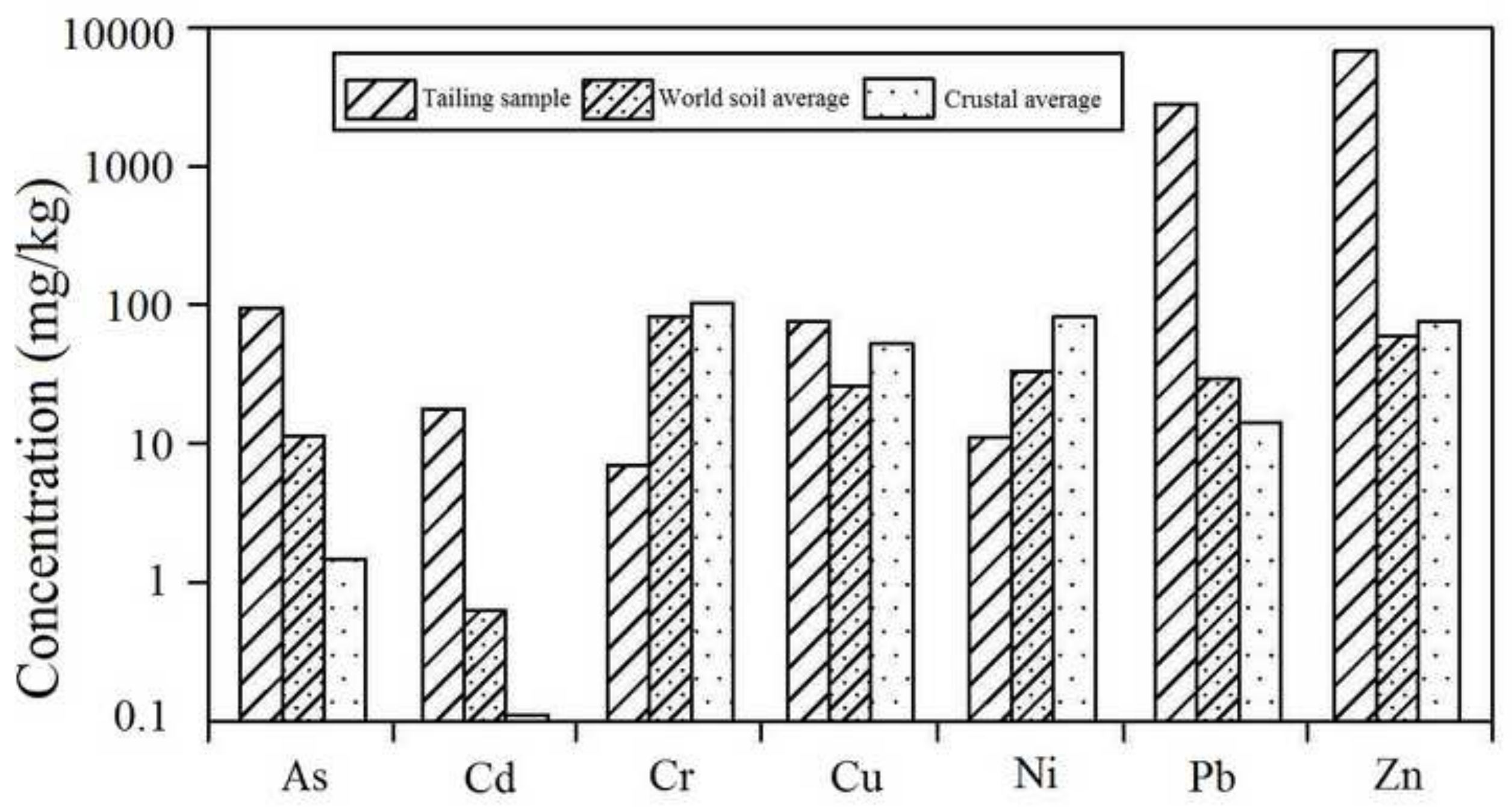




\section{$\square \mathrm{As} \square \mathrm{Cd} \square \mathrm{Cr} \square \mathrm{Cu} \square \mathrm{Ni} \square \mathrm{Pb} \square \mathrm{Zn}$}

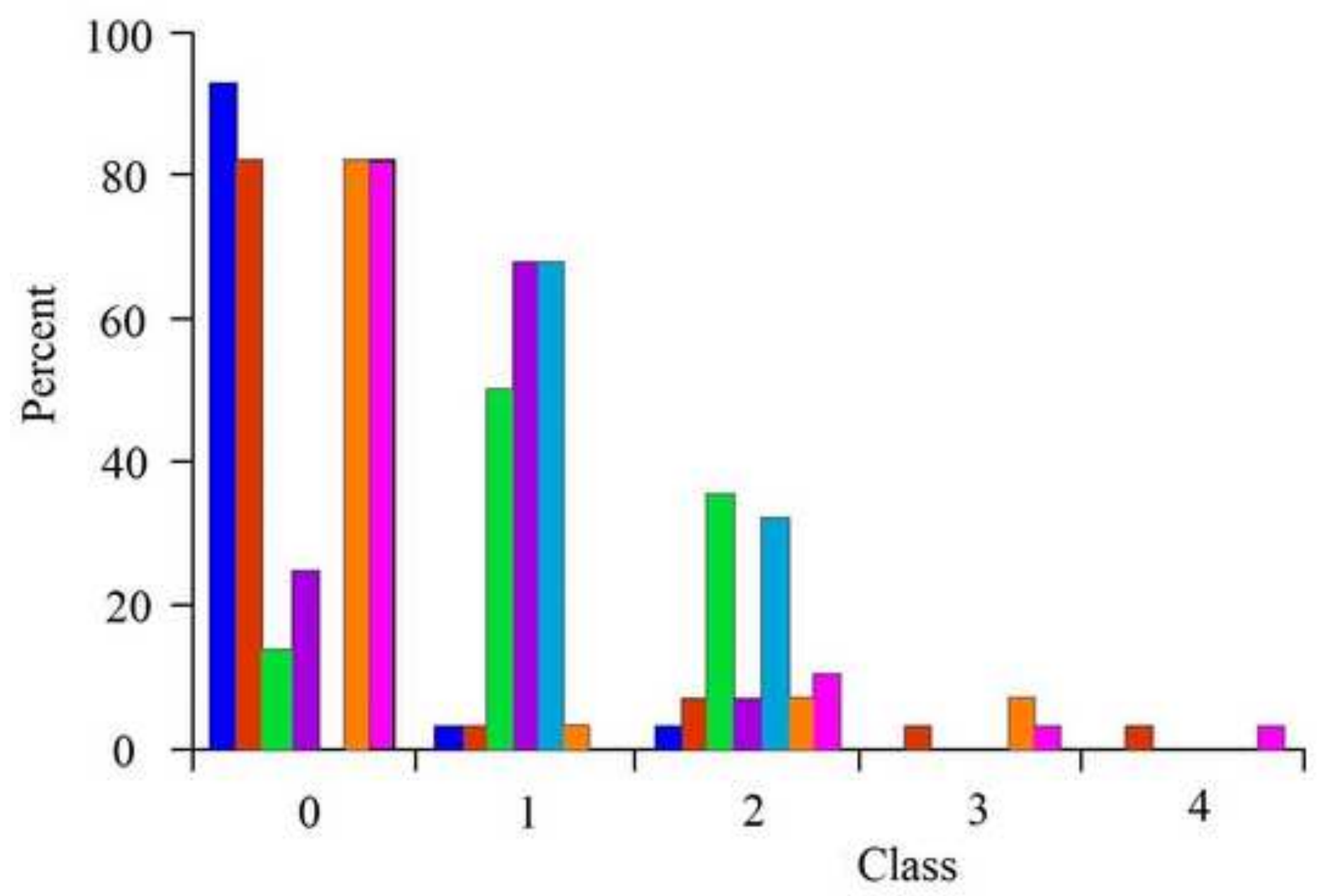



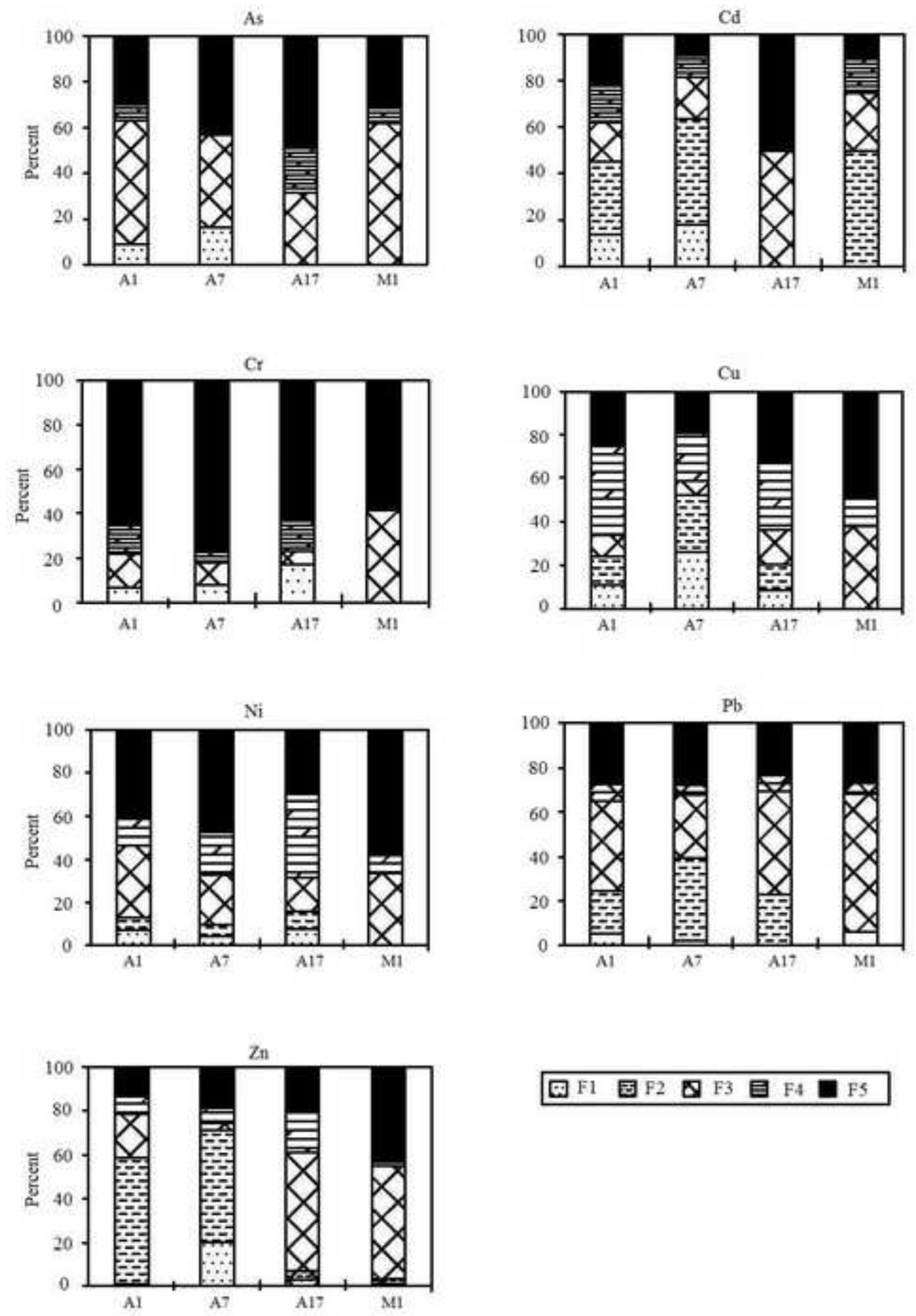

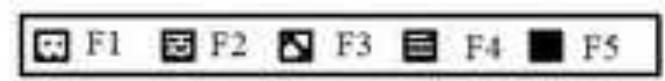


『 Agricultural soils $\square$ Minesoils

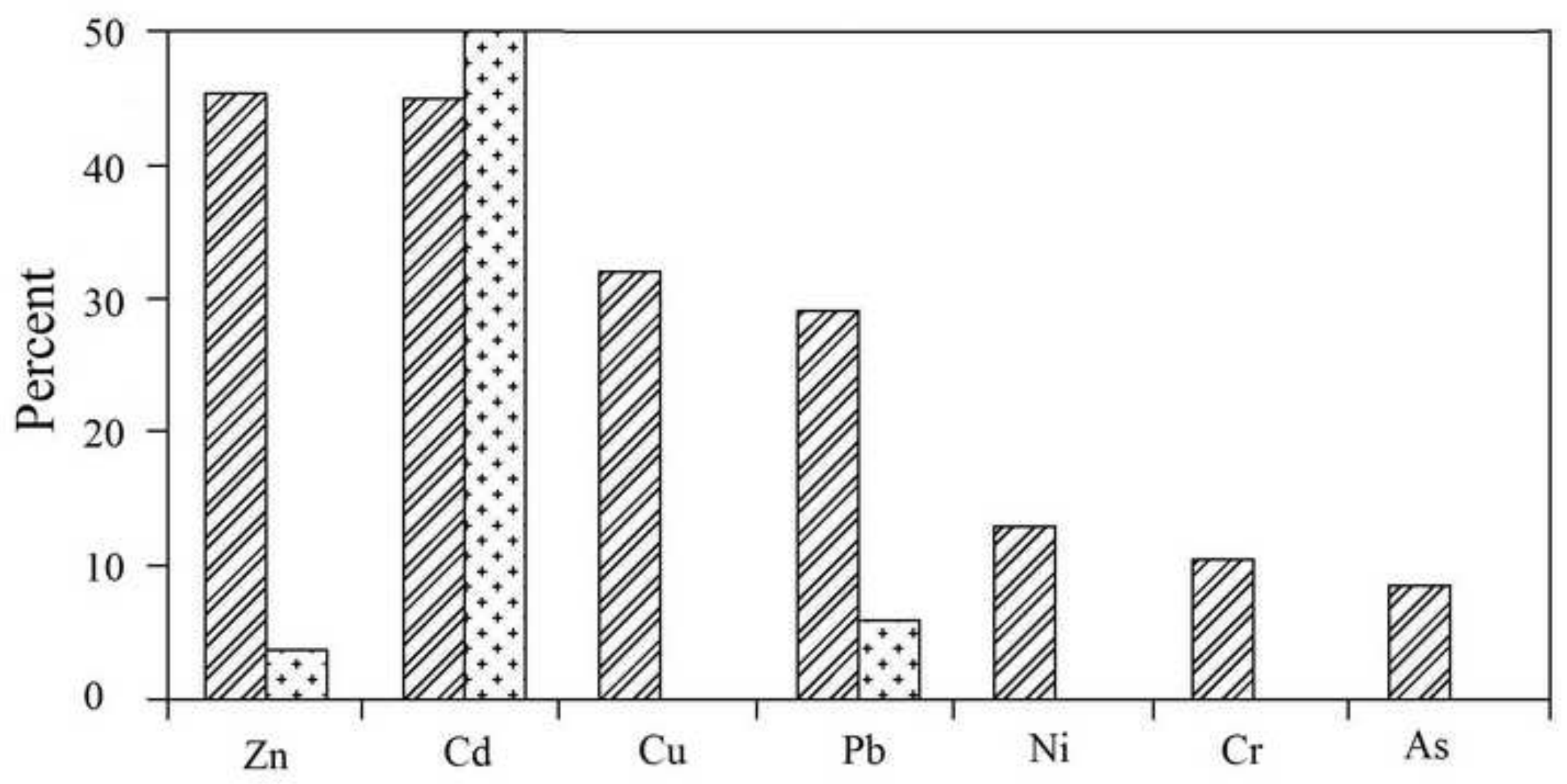


$\square$ Residual (agricultural soils) $\square$ Non-residual (agricultural soils)

园 Residual (minesoil) ÐNon-residual (minesoil)

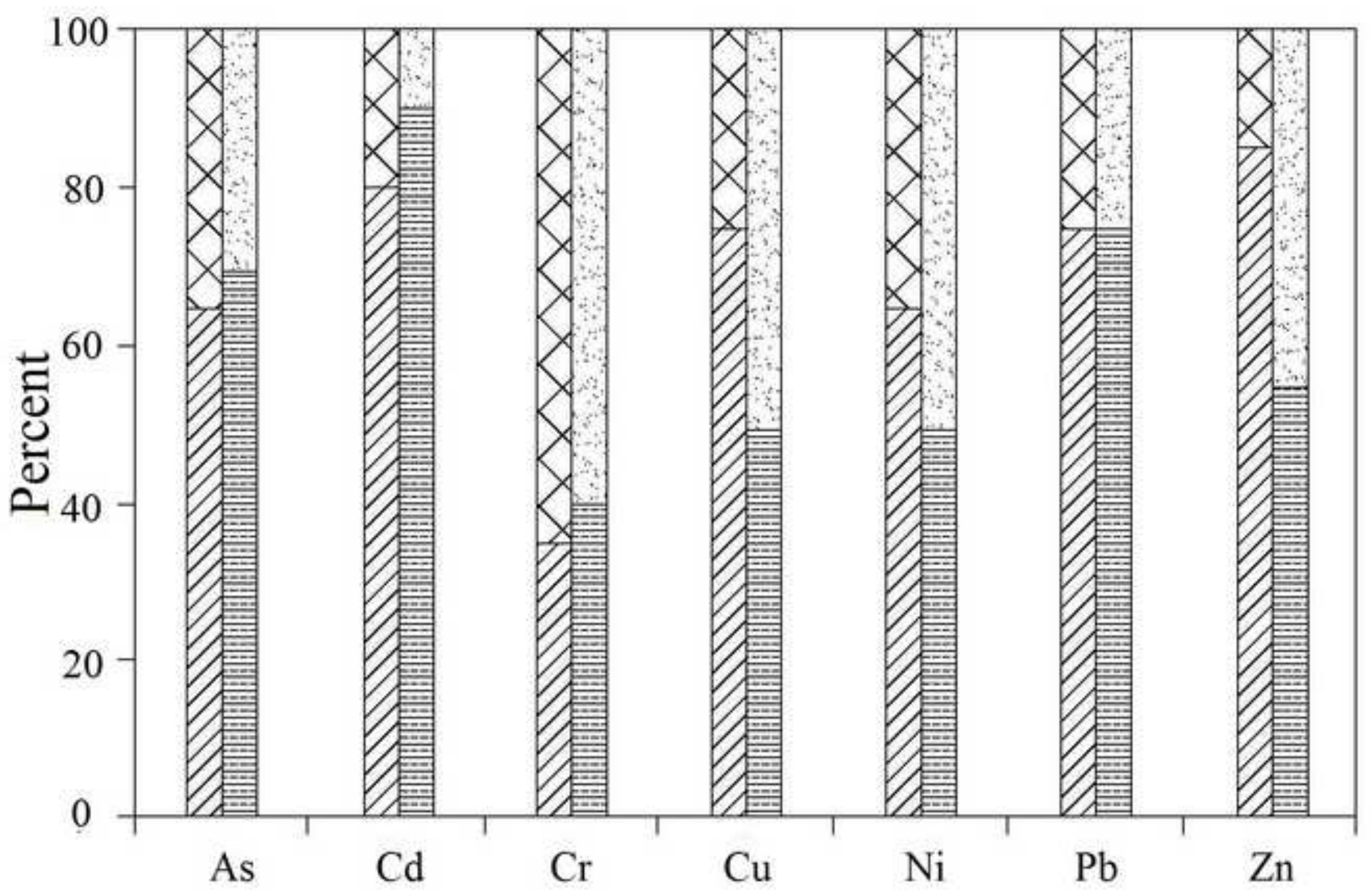

